\title{
The impact of cryopreservation on bone marrow-derived mesenchymal stem cells: a systematic review
}

\author{
Soukaina Bahsoun ${ }^{1}$, Karen Coopman ${ }^{2}$ and Elizabeth C. Akam ${ }^{1 *}$ (D)
}

\begin{abstract}
Mesenchymal stem cells (MSCs) represent an invaluable asset for the field of cell therapy. Human Bone marrowderived MSCs (hBM-MSCs) are one of the most commonly used cell types in clinical trials. They are currently being studied and tested for the treatment of a wide range of diseases and conditions. The future availability of MSCs therapies to the public will require a robust and reliable delivery process. Cryopreservation represents the gold standard in cell storage and transportation, but its effect on BM-MSCs is still not well established. A systematic review was conducted to evaluate the impact of cryopreservation on BM-MSCs and to attempt to uncover the reasons behind some of the controversial results reported in the literature. Forty-one in vitro studies were analysed, and their results organised according to the cell attributes they assess. It was concluded that cryopreservation does not affect BMMSCs morphology, surface marker expression, differentiation or proliferation potential. However, mixed results exist regarding the effect on colony forming ability and the effects on viability, attachment and migration, genomic stability and paracrine function are undefined mainly due to the huge variabilities governing the cryopreservation process as a whole and to the lack of standardised assays.
\end{abstract}

Keywords: Bone-marrow derived mesenchymal stem cells, Cell therapy, Cryopreservation, Mesenchymal stem cells, Tissue culture, Systematic review

\section{Background}

Bone marrow non-hematopoietic stem cells represent a fraction of the bone marrow cell population. They may arise from the constituents of the bone marrow structure and they can differentiate into mesenchymal tissues such as adipose, cartilage and bone. Bone marrow nonhematopoietic stem cells were first mentioned by Julius Cohnheim in 1867 and later cultured and characterized by Freidenstein et al. in the 1970s [1-4]. Friedenstein demonstrated that bone marrow non-hematopoietic stem can be selected by adherence to culture flask and exhibit the following characteristics: fibroblast morphology, colony-forming ability and in vitro proliferation and differentiation potentials [5]; all of which were indicative

\footnotetext{
*Correspondence: e.c.akam@lboro.ac.uk

${ }^{1}$ School of Sport, Exercise and Health Sciences, Loughborough University,

Loughborough, Leicestershire LE11 3TU, UK

Full list of author information is available at the end of the article
}

of 'stemness' properties [6]. With that said, it must be noted that within the scientific community, there is still an ongoing discussion about the true nature of these cells. Two names propagated for these cells "Stromal Stem Cells" [7] and "Mesenchymal Stem Cells" [8, 9].

The then newly discovered source of stem cells has attracted great interest in medical research. In addition to the characteristics listed above, isolating mesenchymal stem cells from bone marrow was surrounded with minimal ethical issues and could substitute embryonic stem cells [6]. Therefore, hBM-MSCs became the subject of intense research and in 1995 the first autologous intravenous infusion of these cells in cancer patients was performed [10]. Later, MSCs have been shown to have widespread immunomodulatory effects [11] as well as an angiogenic induction ability [12]. Taken together these characteristics enlarged the scope of application of hMSC-based therapies. As of April 2019, a search on 
the U.S. National Library of Medicine (ClinicalTrials.gov) using the term 'bone marrow mesenchymal stem cells' retrieved 368 clinical trials aiming to treat conditions like stroke, graft versus host disease, osteoarthritis, crohn's disease, ischemic heart disease and multiple sclerosis.

The future availability of cell therapies to the public will be dependent on easy and quick logistics as well as robust and reliable delivery process. Abazari et al. [13] suggested that if cell therapies "cannot be delivered clinically and logistically then their benefit is irrelevant". Cryopreservation remains the cell therapy industry "standard" for biopreservation [14] as well as the primary option of storage for hMSC-based products [15]. In fact, cryostorage has evolved from being a marginal process in the cell therapy manufacturing process to become a tool widening the availability of stem cell therapy in particular and regenerative medicine in general. However, despite its evolving role, cryobiology is lagging behind the speed at which the cell therapy industry is growing.

Cryopreservation is particularly crucial for a successful cell therapy for various reasons. It facilitates cell transport, it enables the generation of cell banks with indefinite shelf-life thus ensuring off-the-shelf steady supply, access and availability and it gives time for quality control testing and in vitro assays [14, 16, 17]. In addition, cryostoring therapeutic doses of cells in hospitals and clinics could make cell therapy a treatment choice for many diseases and conditions including acute conditions [18]. Furthermore, cryopreserved cells are ideal for sequential treatments such as the case of chronic heart failure or ischemic heart disease to ensure the consistency of the treatment [19]. Banking cells is also an appropriate option from an economical and a regulatory aspect [20]. The logistics of administration of MSC in many immunotherapy trials were simply described as cryopreserving cells, thawing them when needed and administering them within a couple of hours. This scenario would only be feasible if thawed cells preserved their viability, safety and potency [20].

Cryopreservation of cells is associated with several injuries; physical and molecular. A controversy still exists about the efficacy of fresh cells versus cryopreserved and whether viability implies functionality [21]. In early MSC-based clinical trials, using cryopreserved cells was hypothesised to be the source of failure [21]. In addition, the variability in the outcome of MSC-based clinical trials was proposed to mainly be due to the functional alterations that the freeze-thaw process provokes in MSCs rather than the freezing method itself [17].

Human Bone marrow-derived MSCs (hBM-MSCs) are the most commonly used source of MSCs in clinical trials [22] and have been deployed across 17 European centres manufacturing MSCs [23]. The effects of cryopreservation on this type of cells are not well defined. The aim of this review is to assess whether rigorous data exist regarding the impact of the freeze-thawing process on BM-MSCs phenotypic and functional traits. To our knowledge, this is the first review to factor numerous aspects of the freezing process (freezing solution composition, the freezing protocol, the duration of storage, the concentration of cells at freezing, the passage number at freezing as well as the thawing method) in one analysis, for studies conducted over about 20 years. Such detailed analysis may allow firm conclusions to be drawn regarding BM-MSCs performance after the freeze-thawing process as well as help uncover possible reasons behind some of the controversial existing results and highlight areas which require further investigation.

\section{Methods}

The inclusion criteria for this review were: Articles or conference papers assessing the impact of cryopreservation by slow freezing on BM-MSCs in suspension. There was no restriction on the species from which cells were derived. Studies where bone marrow itself was frozen, where freezing of BM-MSCs was done by vitrification or using a 3D structure and where cryopreservation impact was only assessed in vivo, were excluded. A systematic literature search was conducted using PubMed, Science direct and Google Scholar (last search performed April 2019). Two combinations of search terms were used 'cryopreservation mesenchymal' and 'freezing mesenchymal. The output of each search was first scanned for the relevance of title. Articles were excluded if the topic is unrelated or when an eligibility criterion is not met. The retained articles were then screened for the relevance of abstracts (and in few cases materials and methods) and retained when meeting all the eligibility criteria (Fig. 1). From the 41 retained studies, information regarding the freezing solution composition, the freezing protocol, the duration of storage, the concentration of cells at freezing, the passage number at freezing as well as the thawing method was extracted and tabulated. Next, studies were grouped in tables according to the "hMSC checklist" proposed in [24]. Cell surface marker expression, differentiation potential, proliferation and growth, attachment and migration potential, genomic stability and paracrine function were examined. In addition, post-thaw viability and morphology information was also collated because they are primary evaluators of cryopreservation.

\section{Results}

Species, freezing and thawing methods

As shown in Fig. 141 studies met the inclusion criteria. MSCs were isolated from the bone marrow of 10 different species which included human (26 studies), rat 


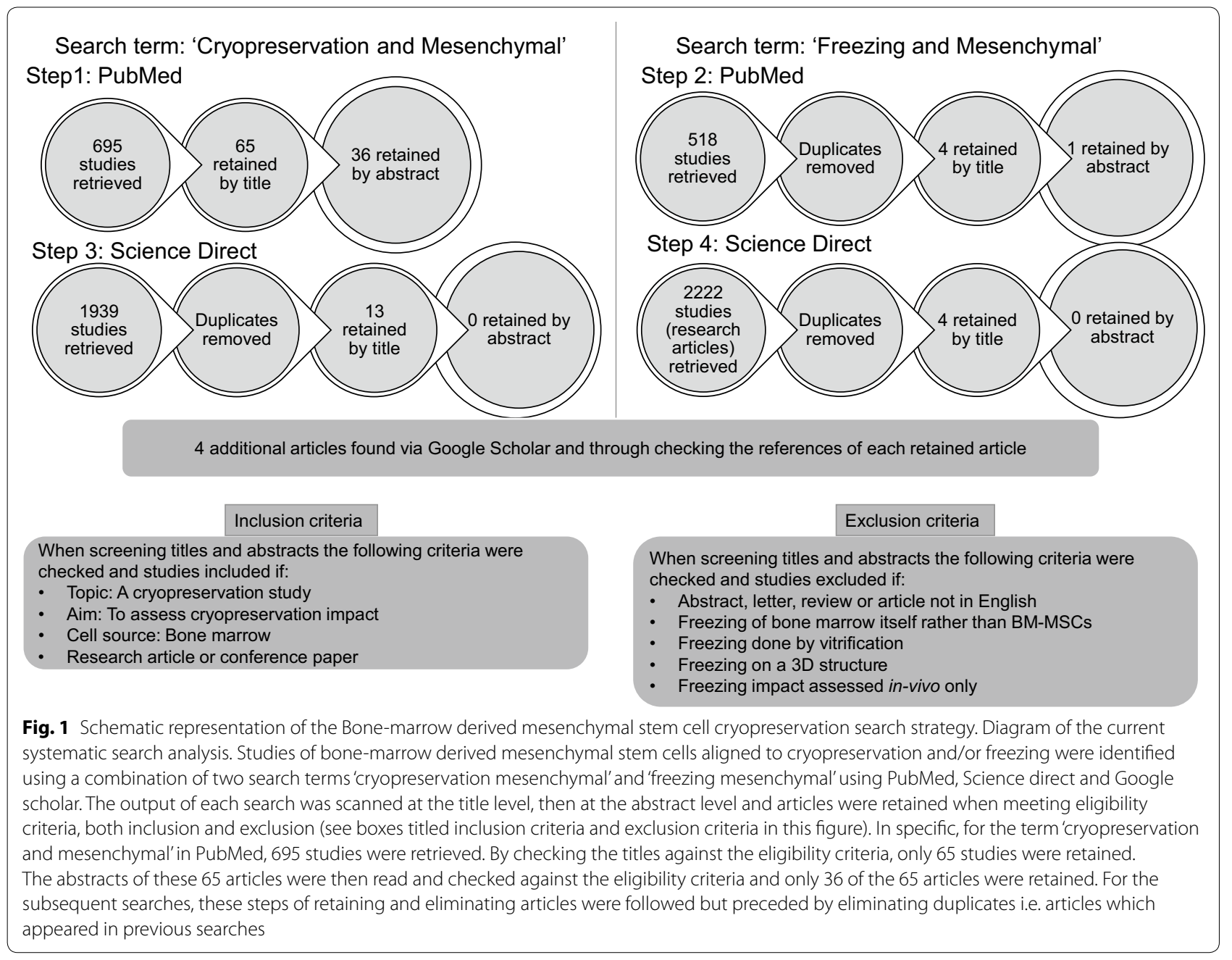

(5 studies), monkey (3 studies), dog (3 studies), horse (2 studies), pig (2 studies), minipig (1 study), mouse (1 study), calf (1 study) and sheep (1 study) (Fig. 2).

Across the retained studies, various freezing media formulations were used. $20 \%$ of studies (17\% human) used commercially available freezing solution such as CELLBANKER and CRYOSTOR while the rest used "in-lab" homemade formulations. $66 \%$ of studies ( $41 \%$ human) used or tested various amounts of serum in the freezing media with the serum principally being animal-derived, $20 \%$ of studies (12\% human) froze cells in serum-free media while $5 \%$ used freezing media containing plasma or human platelet lysates (all of which are human studies). For $17 \%$ of the studies, not enough information was included about FBS content and/or about the composition of the freezing medium (12\% human). Of the serum-free studies, one study assessed the efficiency of Sericin as a substitute

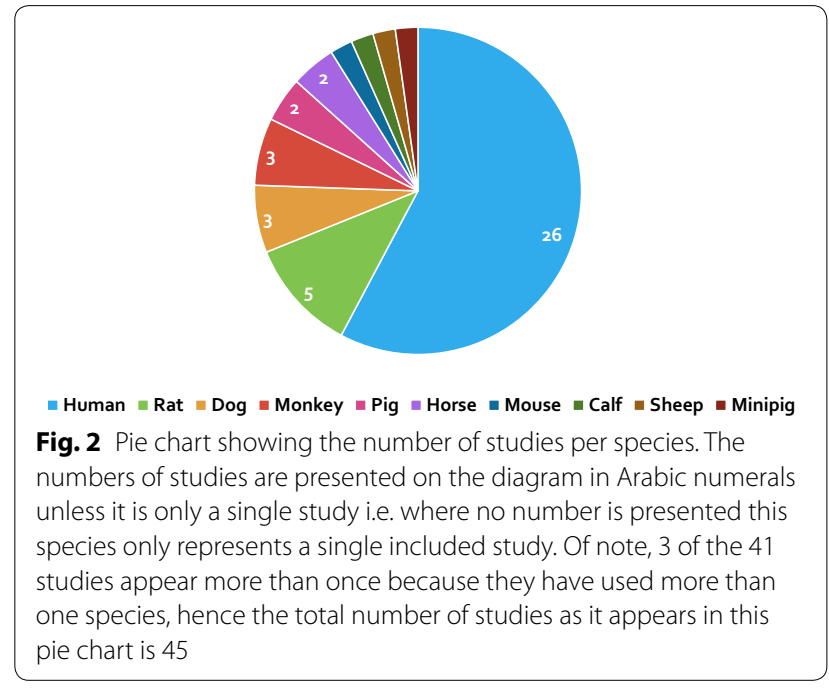


to FBS [25]. Across all of the studies, 13 assessed the freezing in xeno-free media. More than $90 \%$ of studies used dimethylsulfoxide (DMSO) at a concentration ranging from 1 to $20 \%$ with $10 \%$ being the most commonly used. Carboxylated poly-L-lysine (COOH-PLL) was investigated as a cryoprotectant to replace DMSO [26] and hydroxyethyl starch was added to freezing solution as a strategy to reduce the percentage of DMSO [27]. Two studies tested various freezing solutions containing polyethylene glycol (PEG), trehalose and 1,2 propanediol in order to develop a well-defined, serum-free and reduced-DMSO freezing solution $[28,29]$. Only two studies utilized strategies to prevent post-thaw apoptosis through the addition of Rho-associated kinase inhibitor [30] and Caspase inhibitor z-VAD-fmk [31] in the freezing media.

Concerning freezing protocols, two procedures prevail. The first involves incubating the cells at a freezing rate of $-1{ }^{\circ} \mathrm{C} / \mathrm{min}$ in a $-80{ }^{\circ} \mathrm{C}$ freezer for several hours (up to $24 \mathrm{~h}$ ) then moving the cells to liquid nitrogen $\left(\mathrm{LN}_{2}\right)$. The second is based on a two to seven-step sequential freezing process using a programmable freezing device to freeze the cells prior to $-150{ }^{\circ} \mathrm{C}$ freezer or $\mathrm{LN}_{2}$ storage. Four studies reported whether cells were stored in liquid phase [32] or vapour phase [30,33,34] of $\mathrm{LN}_{2}$. Five studies stored the cells at $-80{ }^{\circ} \mathrm{C}[26,35-38]$ and 1 study stored the cells at $-70^{\circ} \mathrm{C}[39]$.
Seven studies (3 human and 4 animal) did not specify the passage number at which cells were frozen. Six studies ( 3 human and 3 animal) used cells at passage 1, one study (monkey) used cells at passage 9 and the rest (20 human and 6 animal) used cells at passages ranging from 1 to 6 . The concentration of cells at freezing was very variable ranging from $1 * 10^{5}$ to $1 * 10^{7}$ cells $/ \mathrm{mL}$ with $1 * 10^{6}$ cells $/ \mathrm{mL}$ being the most frequently used (17 studies; 9 human and 8 animal). There was only one study in which human-derived cells were frozen in cryopreservation bags at a concentration of $1.8^{*} 10^{8}[40]$. There was a huge variation regarding the duration of storage of cells in the frozen state; the shortest period being $1 \mathrm{~h} \mathrm{[30]}$ and the longest 10 or more years [37].

Seven studies (human) did not include information about their thawing protocols. Two studies (1 human and 1 animal) just mentioned 'quickly thawed' [20,39], one in $\alpha$-MEM [41], one at room temperature [37] and one in a $37{ }^{\circ} \mathrm{C}$ incubator [42]. For all the rest (16 human and 13 animal), there was some consistency; cells were typically thawed at $37^{\circ} \mathrm{C}$, most likely in a water bath with or without gentle agitation for 1-4 min.

\section{Post-thaw assessment}

Presented in Fig. 3 are how many of the forty-one retained studies assessed different cellular attributes,

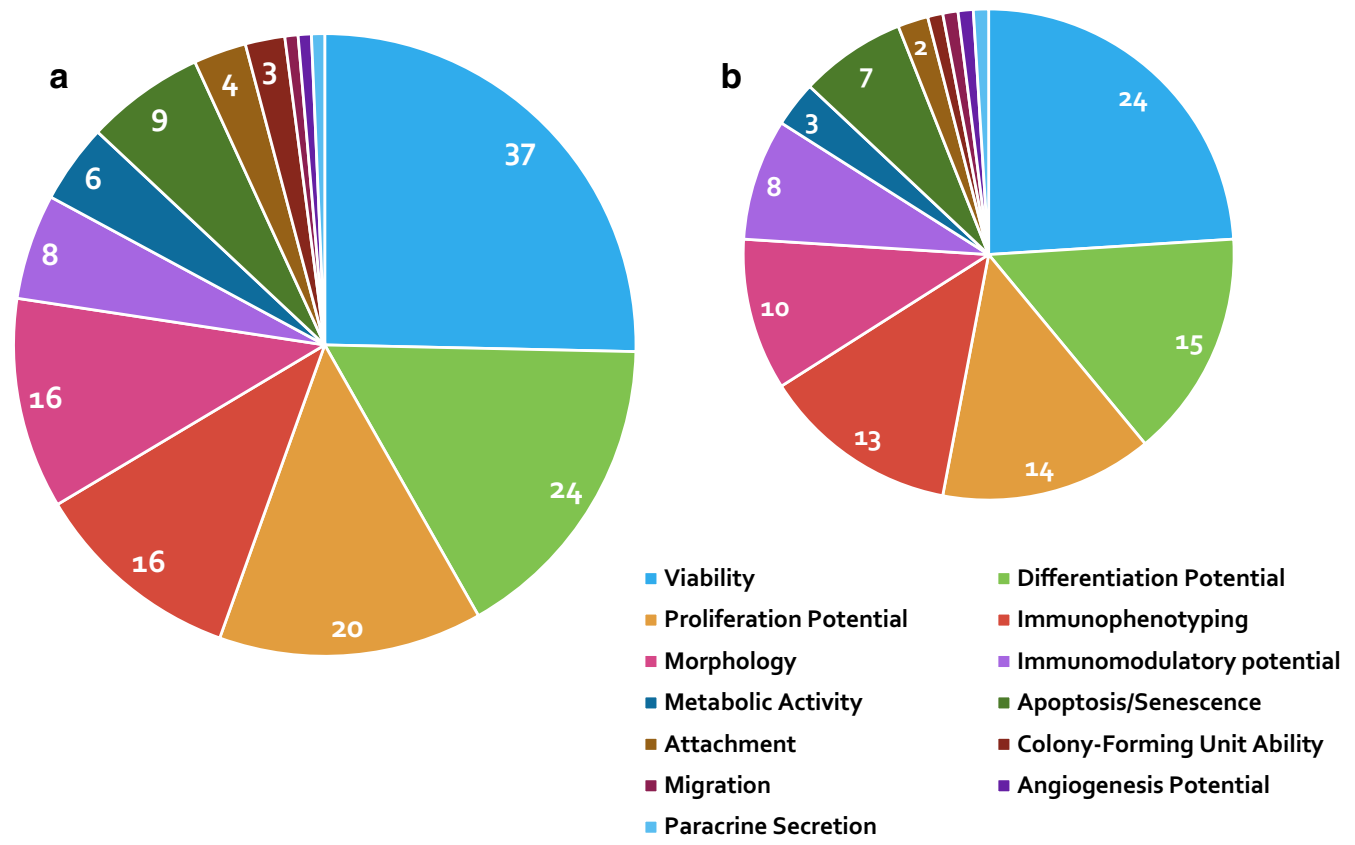

Fig. 3 a Pie chart showing the proportion of the retained studies assessing different cellular attributes in all species. $\mathbf{b}$ Pie chart illustrating the proportion of human retained studies assessing different cellular attributes. It is supported by Additional file 1 which aggregates and delineates which studies undertook which analyses in a tabular form [arranged by species: human (chronologically and then alphabetically) and animals from most to least frequent species (chronologically and then alphabetically)]. Additional file 1 is a grid identifying which cell attributes each of the forty-one studies assessed. Of note each of the 41 studies may appear more than once depending on the attributes they assessed 
it shows that viability and differentiation potential are the only attributes assessed in over half of the retained studies.

\section{Viability}

Post-thaw viability was the most assessed cell attribute (37 studies). Table 1 lists the studies which assessed viability immediately post-thaw (37 studies) or after a period of post-thaw culture, which was monitored in five studies (post-thaw time point from $4 \mathrm{~h}$ to 3 passages). Three main methods for viability assessment were used; trypan blue exclusion, flow cytometry and fluorescent microscopy. The immediately post-thaw viability varied from about $50 \%$ to $100 \%$ which is noteworthy. Sixteen studies reported no change in viability immediately after thawing while 10 studies reported significantly lower viability. In some studies where a new freezing formulation was tested, viability was compared to $10 \%$ DMSO which is still considered the gold standard for freezing BMMSCs. The timing of viability measure is crucial due to the induction of apoptotic events some time post-thaw [43]. As mentioned above only five studies assessed the long-term effect (up to 3 passages post-thaw of freezing) with two reporting lower viability and three reporting no effect. It was also noted that variability in the level of viable cells within the same study differed when using different methods of measurement such as trypan blue exclusion compared to flow cytometry $[44,45]$.

\section{Morphology}

Table 2 summarises the studies which assessed post-thaw cell morphology. This attribute was mainly assessed using microscopy. Irrespective of all the variables considered in this data analysis and the time post-thaw at which cell morphology was checked, 13 of the 16 studies agree that cryopreservation itself has no effect on post-thaw cell morphology. The addition of Rho-associate kinase (ROCK) inhibitor Y-27632 was reported to give BMMSCs a web-like appearance which indicated some neuronal differentiation [30]. In addition, several cell shapes were observed at day 2 and day 5 post-thaw [46] and cell shrinkage was detected using flow cytometry [38].

\section{Immunophenotyping}

Marker expression is one of the International Society for Cellular Therapy (ISCT) criteria for defining MSCs [47] so it is of real importance to check BM-MSCs phenotype before freezing and/or after thawing. Table 3 lists the studies which assessed BM-MSCs marker expression post-thaw. Despite its importance, less than half of the 41 studies retained assessed post-thaw marker expression retention and despite all the variables taken into consideration in this investigation, there was a consensus regarding the methodology used (flow cytometry) and the results; cryopreservation does not affect BM-MSCs immunophenotype.

\section{Differentiation potential}

Tri-lineage differentiation (adipogenic, osteogenic and chondrogenic) is another criterion listed by the ISCT guide for defining MSCs [47]. Hence, more than half of the studies [24] assessed BM-MSCs post-thaw differentiation potential and these are listed in Table 4. Osteogenesis is the most frequently assessed differentiation pathway (20 studies) qualitatively through Alizarin red staining and/or quantitatively through measurement of alkaline phosphatase activity. There was an agreement among 18 studies that cryopreservation did not affect BM-MSCs osteogeneic potential. One study reported lower osteogenesis [39] and one reported improved osteogenesis post-thaw [48]. Adipogenesis was next in terms of frequency of testing using Oil Red $\mathrm{O}$ staining as a qualitative assessment and no effect of cryopreservation was observed in 12 studies. Only one study provided a quantitative assessment of adipogenesis and it was the only one reporting lower differentiation level [49].

Chondrogenesis presented as the least studied tri-linage differentiation pathway. Only five studies differentiated thawed BM-MSCs into chondrocytes with a qualitative assessment made via Alcian Blue staining. It was concluded that cryopreserved cells did not lose the ability to chondrogenic differentiation (of note thawed BM-MSCs were also able to commit to neuronal and endothelial lineages).

\section{Proliferation potential}

Table 5 lists the 20 studies which examined post-thaw BM-MSCs proliferation potential. Various methods were used to determine proliferation rate such as population doublings and DNA quantification. The majority of results agree that cryopreservation does not affect post-thaw BM-MSCs proliferation potential, nonetheless lower proliferation rate was obtained by two studies [34,39] and higher proliferation rate was obtained by one study [50]. Colony-forming unit ability, a traditional measure of BM-MSCs proliferation, was assessed by three studies with mixed results $[25,32,51]$.

\section{Metabolic activity}

Table 6 lists the six studies which examined post-thaw BM-MSCS metabolic activity. Three methods were equally used to determine cell metabolic activity; AlamarBlue, Presoblue and MTT (3-(4,5-dimethylthiazol-2-yl)-2,5-diphenyltetrazolium) reduction-based assays. From the data collated it could be seen that two-thirds of experiments performed reported impaired metabolic activity post-thaw. 


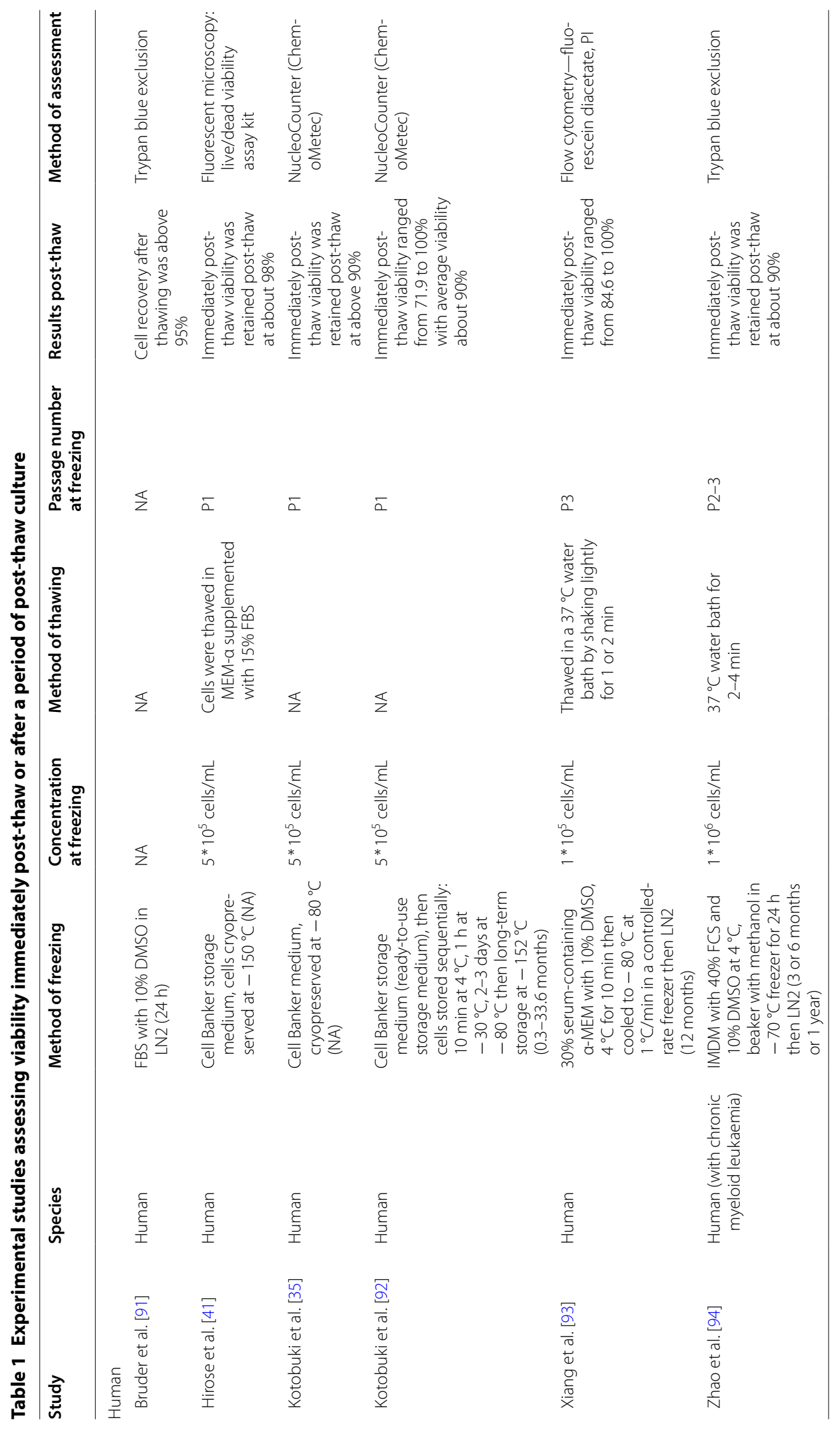




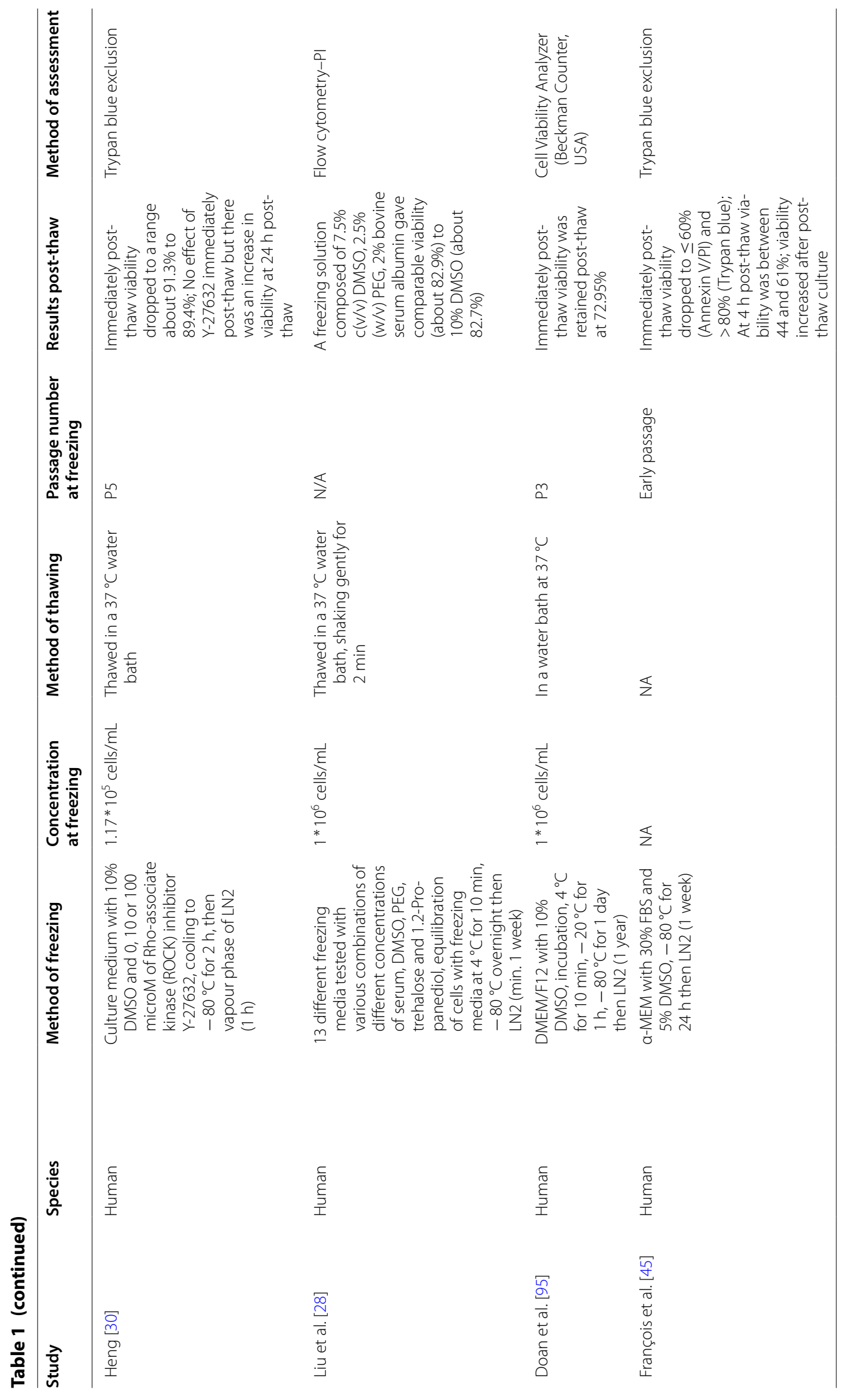




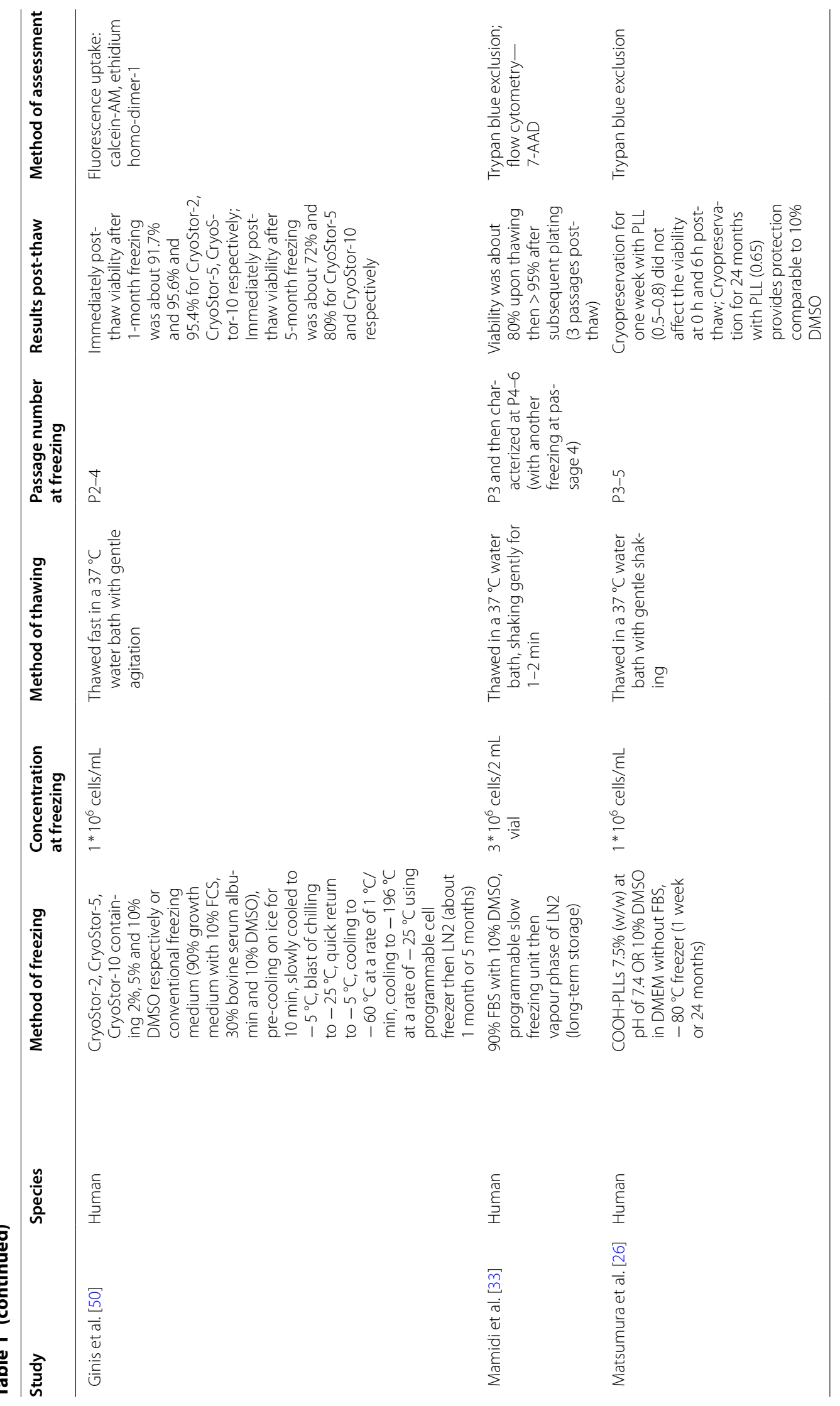




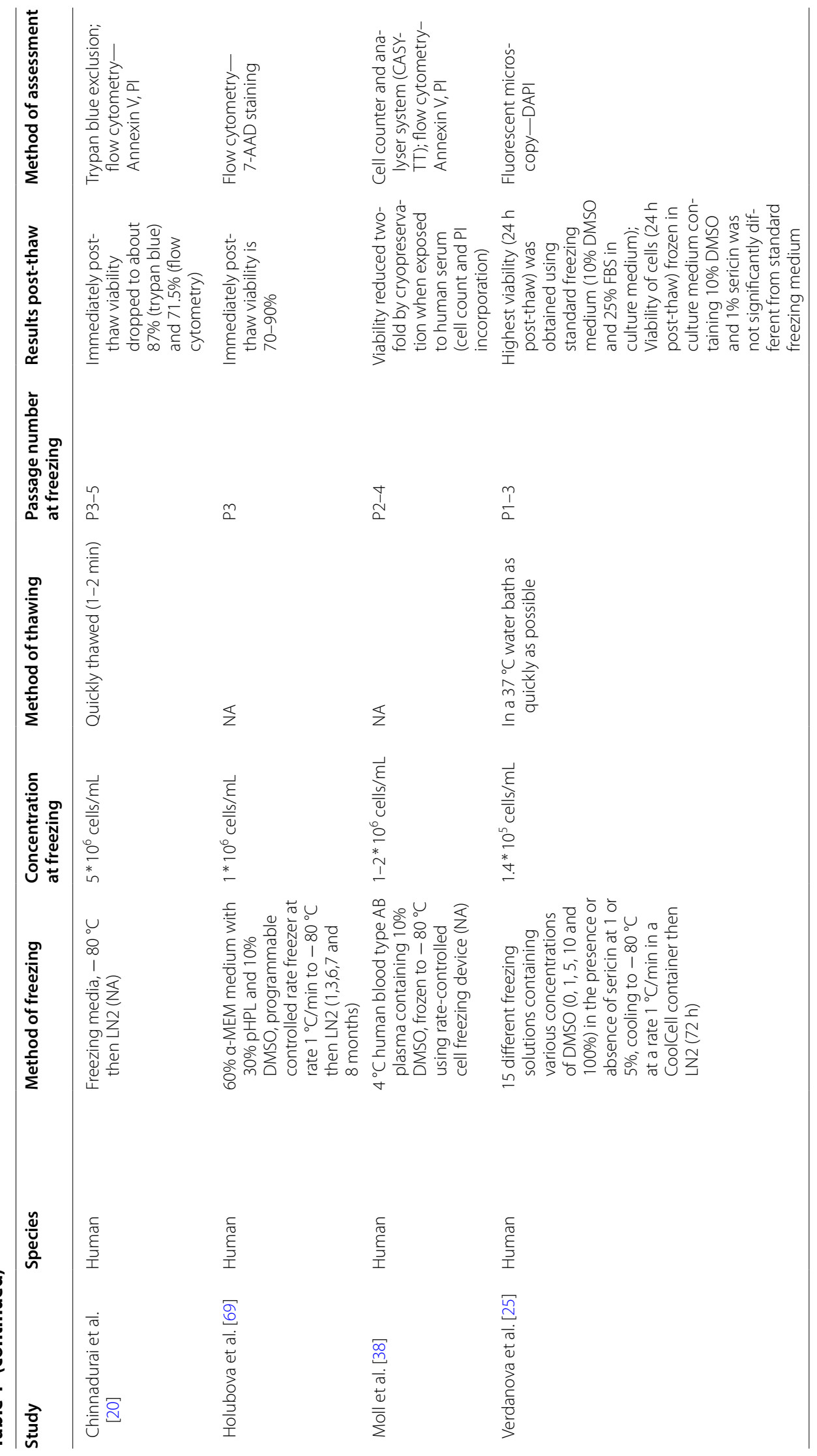


Bahsoun et al. J Trans/ Med ～（2019） 17:397

Page 10 of 29

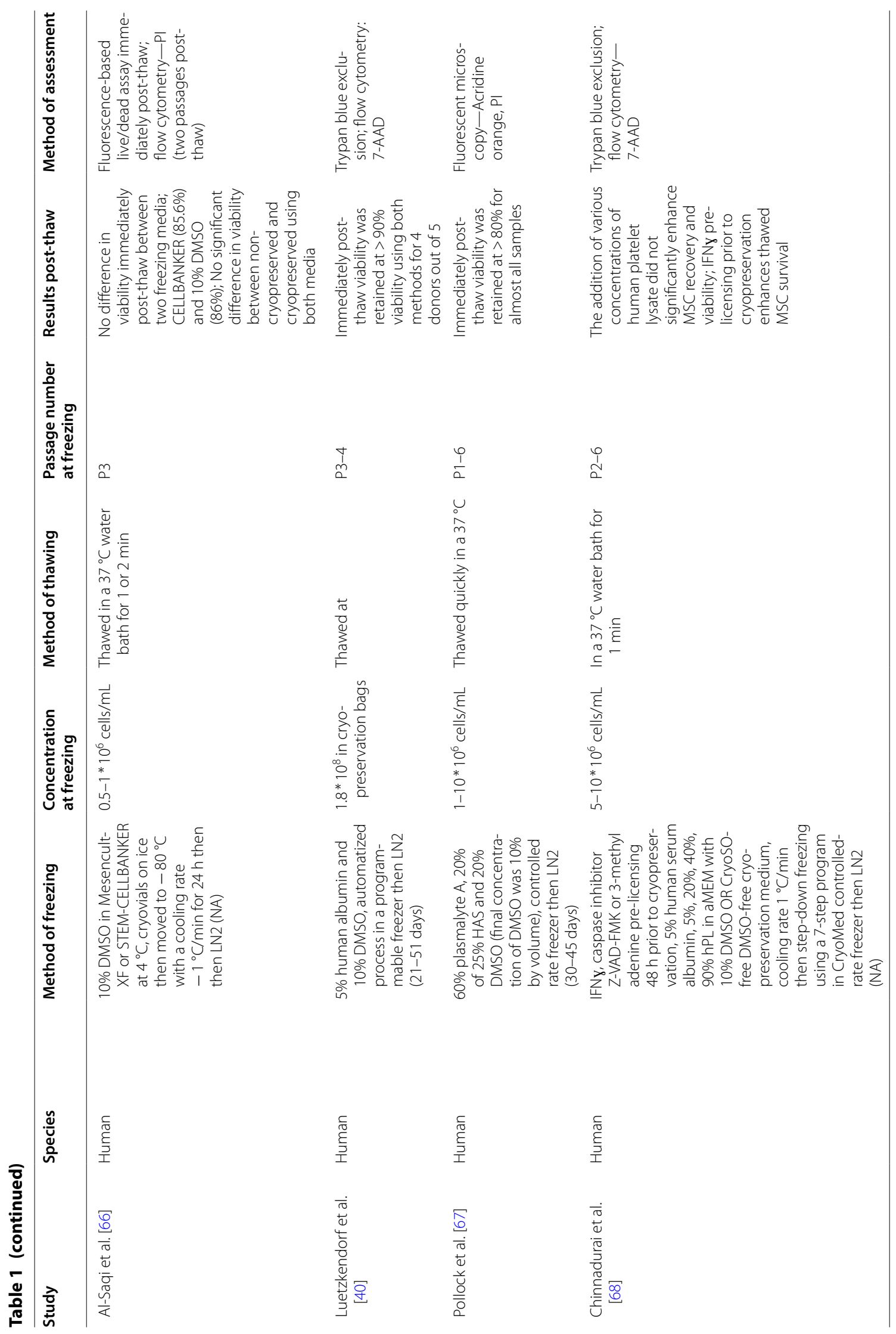




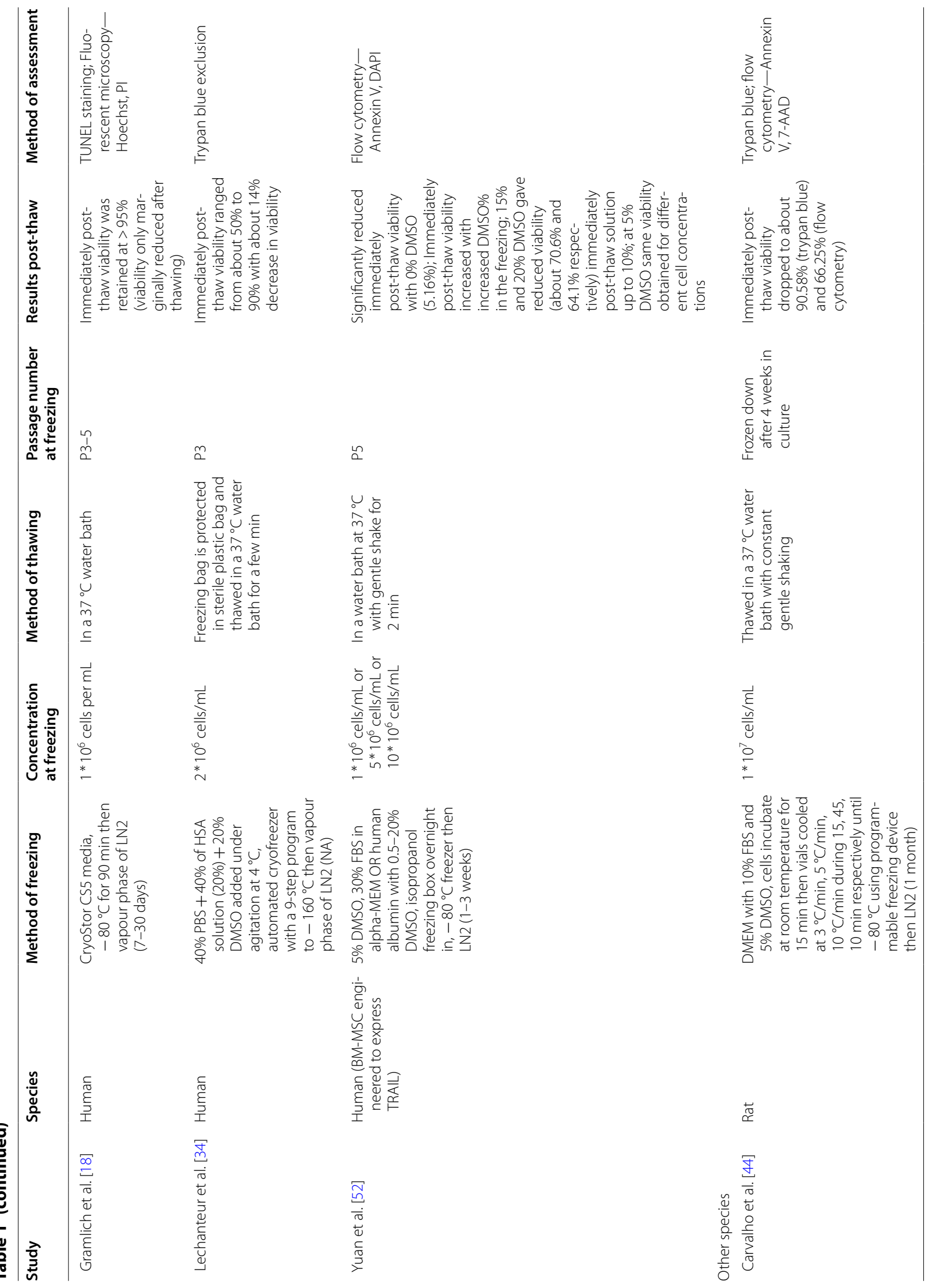




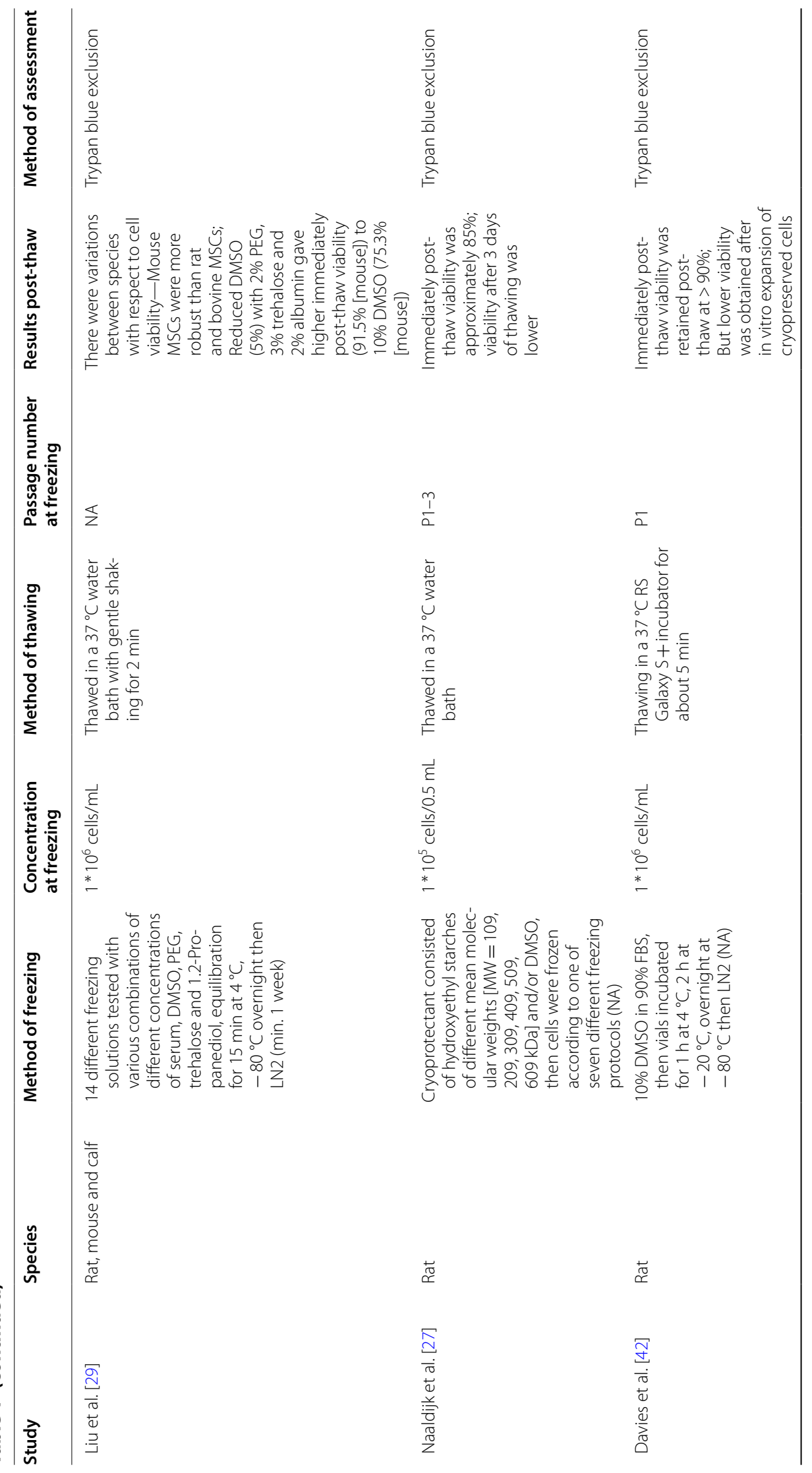




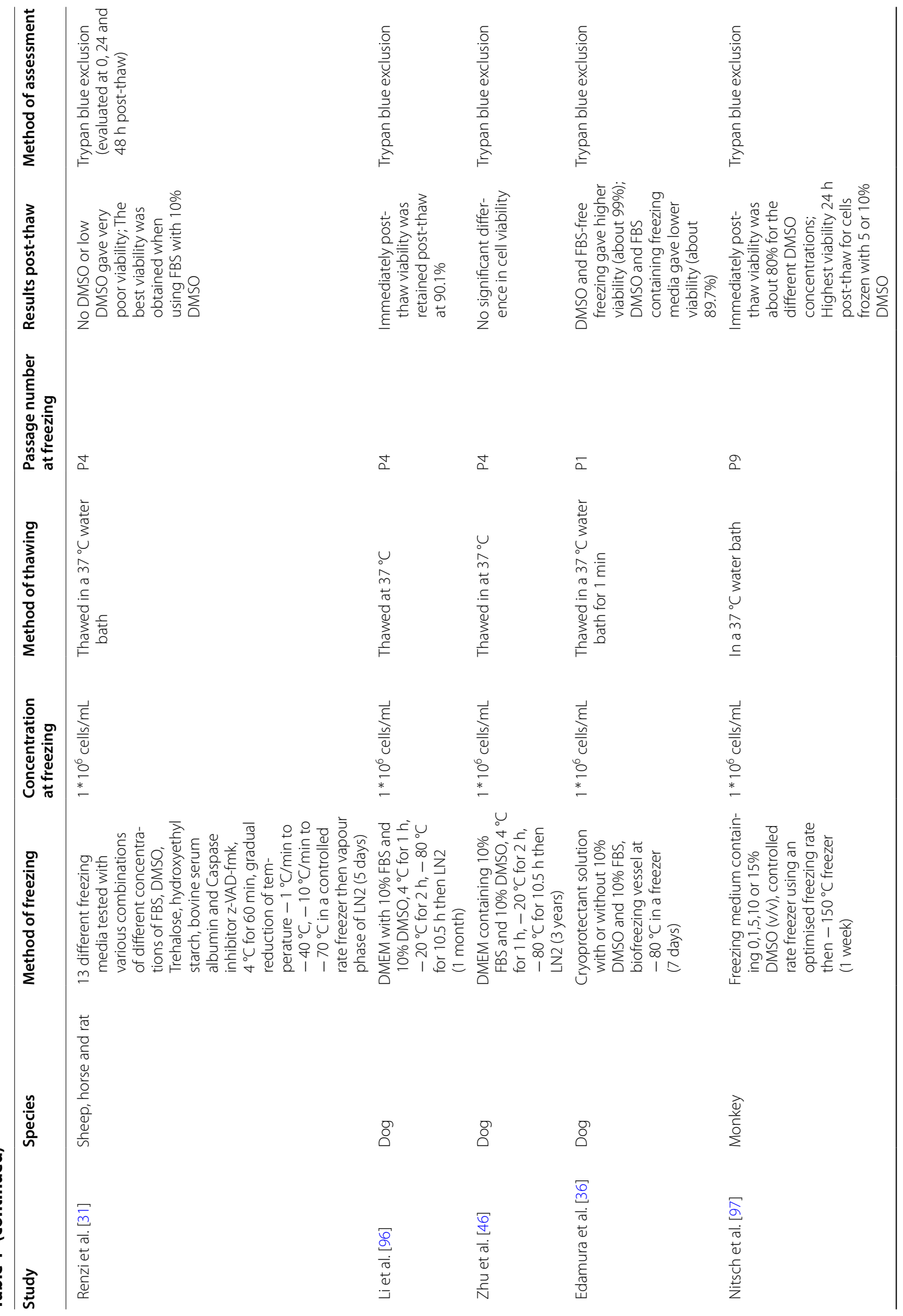




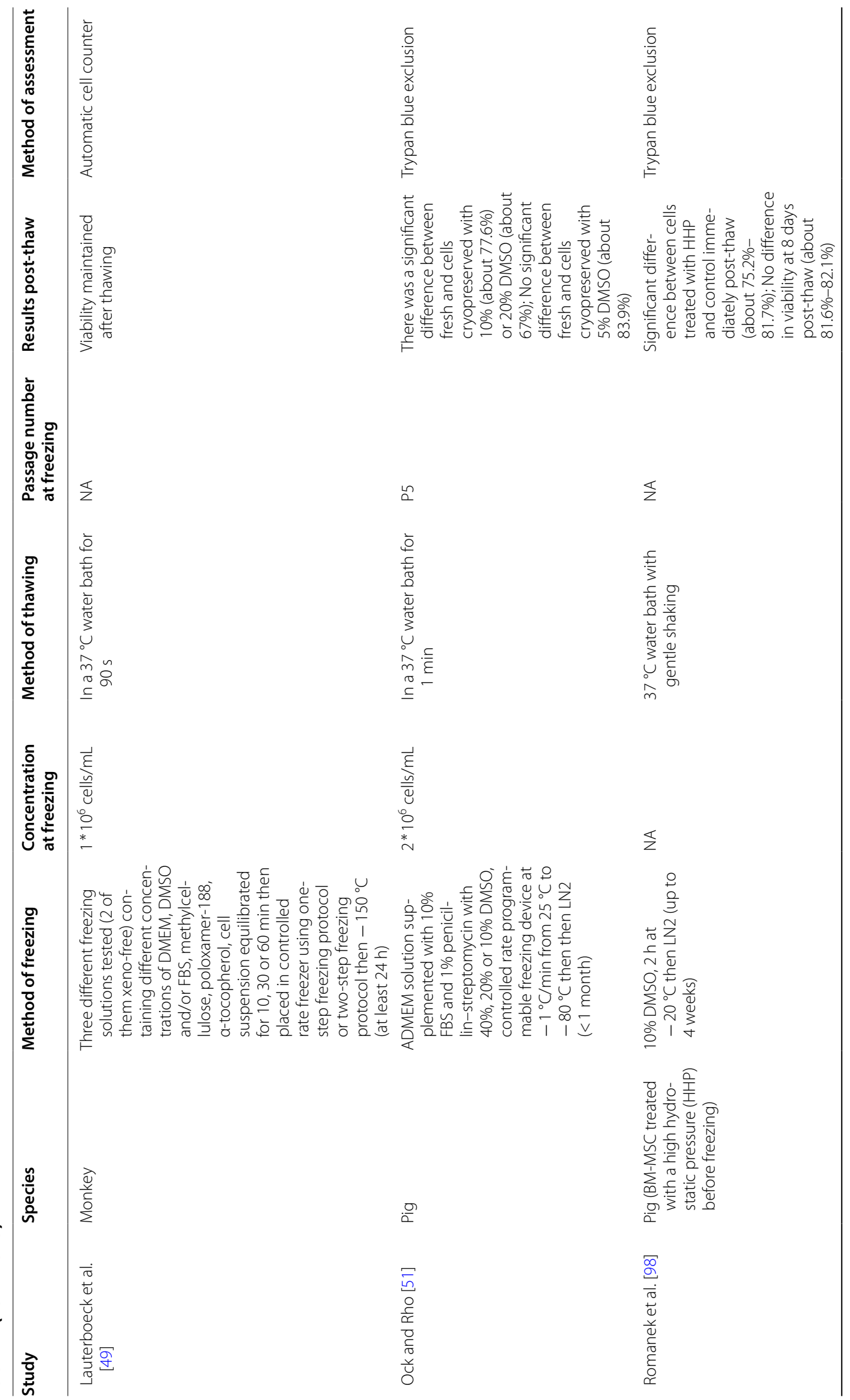




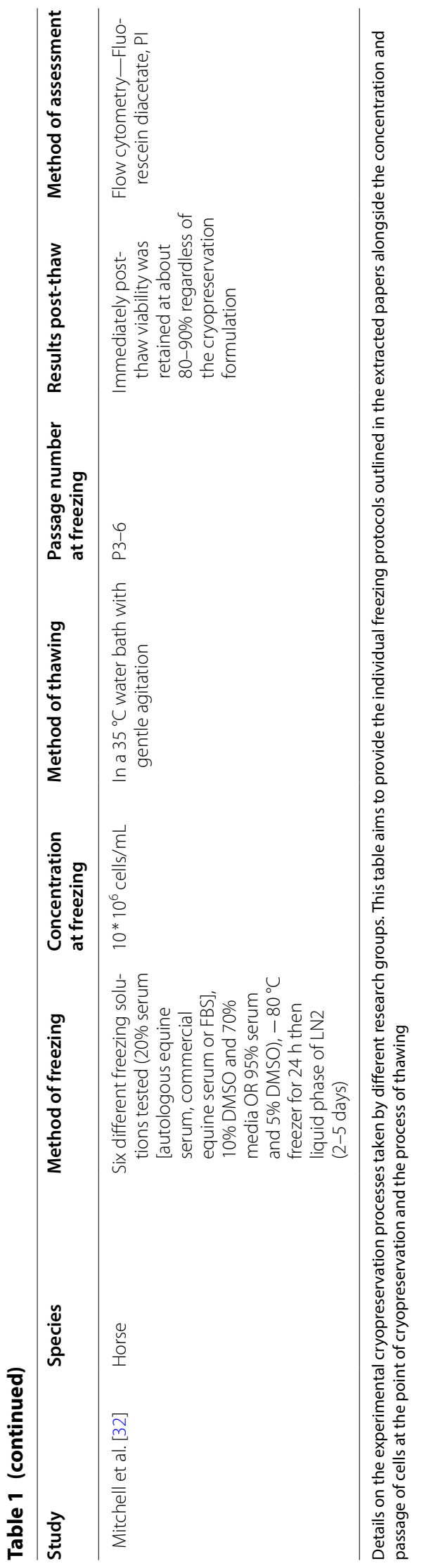


Table 2 Bone-marrow derived mesenchymal stem cell studies assessing post-thaw cell morphology

\begin{tabular}{|c|c|c|c|}
\hline Study & Species & Results post-thaw & Method of assessment \\
\hline \multicolumn{4}{|l|}{ Human } \\
\hline Kotobuki et al. [92] & Human & No effect on morphology & Microscopy (fluorescent/phase contrast) \\
\hline Haack-Sorensen et al. [19] & Human & No effect on morphology & NA \\
\hline Xiang et al. [93] & Human & No effect on morphology & Microscopy (light) at cell confluency post-thaw \\
\hline Zhao et al. [94] & $\begin{array}{l}\text { BM-MSC (human with } \\
\text { chronic myeloid } \\
\text { leukemia) }\end{array}$ & No effect on morphology & NA \\
\hline Heng [30] & Human & $\begin{array}{l}\text { The addition of Y-27632 altered the morphol- } \\
\text { ogy of the cells (web-like appearance) }\end{array}$ & NA \\
\hline Liu et al. [28] & Human & No effect on morphology & Microscopy (fluorescent) \\
\hline Doan et al. [95] & Human & No effect on morphology & Microscopy (light) 7 days post \\
\hline Mamidi et al. [33] & Human & No effect on morphology & NA \\
\hline Moll et al. [38] & Human & $\begin{array}{l}\text { Effect of cryopreservation seen on forward } \\
\text { scatter but not side scatter when exposed to } \\
\text { human serum }\end{array}$ & $\begin{array}{l}\text { Microscopy; cell counter and analyser system } \\
(\text { CASY-TT); Flow cytometry }\end{array}$ \\
\hline Al-Saqi et al. [66] & Human & No effect on morphology & Microscopy (light) two passages post \\
\hline \multicolumn{4}{|l|}{ Other species } \\
\hline Liu et al. [29] & Rat, mouse and calf & No effect on morphology & Microscopy (light) \\
\hline Naaldijk et al. [27] & Rat & No effect on morphology & Microscopy (light) \\
\hline Davies et al. [42] & Rat & No effect on morphology & Microscopy (phase contrast) \\
\hline Zhu et al. [46] & Dog & $\begin{array}{l}\text { Cells had several shapes such as long fusiform, } \\
\text { polygon and astroid }\end{array}$ & Checked at days 2 and 5 after thawing NA \\
\hline Edamura et al. [36] & Dog & No effect on morphology & Microscopy (light) \\
\hline Mitchell et al. [32] & Horse & No effect on morphology & Microscopy (light) (24 and 72 h post) \\
\hline
\end{tabular}

The key results on bone-marrow derived mesenchymal stem cell morphology are presented in this table. For further details on the cryopreservation experimental details refer to either Table 1 or Additional file 2 which provide the individual freezing protocols outlined in the extracted papers alongside the concentration and passage of cells at the point of cryopreservation and the process of thawing

\section{Apoptosis and senescence levels}

Typically assessed using flow cytometry, the induction of apoptosis is evident when considering the six studies entered in Table 7. However, cryopreservation does not seem to induce senescence (refer Table 7) although more studies are needed to draw a firm conclusion.

\section{Attachment and migration}

Only four studies assessed BM-MSCs attachment ability post-thaw, and these are recorded in Table 8. This table indicates that frozen cells have lower adherence capability post-thaw. Only one study assessed post-thaw cell migration [52]. It concluded that cryopreservation has no effect on post-thaw cell migration ability.

\section{Paracrine function}

Paracrine function is related to two main MSCs activities namely immunomodulation and angiogenesis. In total, 10 studies (Refer Table 9) assessed BM-MSCs paracrine function with immunomodulation being the most frequently assessed with eight studies. The results of these studies are equally balanced with four of them reporting no effect of cryopreservation on BM-MSCs post-thaw immunomodulatory potential and four reporting an impaired potential. Angiogenesis potential and secretion of growth factors were only assessed by one study each with no effect of cryopreservation reported.

\section{Discussion}

A recent analysis of MSC-based clinical trials showed that although no safety concerns surround MSC infusion, the translation from bench to bedside is still confronted by what the authors called the 'Achilles heel'; donor heterogeneity, ex vivo expansion, immunogenicity and cryopreservation [53]. There is no doubt that cryopreservation is essential for MSC therapy translation, both autologous and allogeneic, and is still one the limitations to be addressed.

Cryopreservation by slow freezing can cause two types of cell damage; physical and molecular. Physical injuries were the first to be identified and include ice nucleation, solution effects, osmotic shock, cold shock as well as cryoprotectant toxicity [14]. Molecular injuries encompass the effect of cryopreservation on gene expression, protein levels, cell functionality, the induction of stress response as well as post-thaw epigenetic changes $[54,55]$. 
Table 3 Bone-marrow derived Mesenchymal Stem Cell studies evaluating surface marker expression post-thaw

\begin{tabular}{|c|c|c|c|}
\hline Study & Species & Results post-thaw & Method of assessment \\
\hline \multicolumn{4}{|l|}{ Human } \\
\hline Kotobuki et al. [92] & Human & No difference & Flow cytometry \\
\hline Haack-Sorensen et al. [19] & Human & No difference & Flow cytometry \\
\hline Xiang et al. [93] & Human & No difference & $\begin{array}{l}\text { Fluorescent sorting at passage 1, 5, } 10 \text { and } 15 \\
\text { post-thaw }\end{array}$ \\
\hline Zhao et al. [94] & $\begin{array}{l}\text { Human (with } \\
\text { chronic } \\
\text { myeloid } \\
\text { leukaemia) }\end{array}$ & No difference & Flow cytometry \\
\hline Doan et al. [95] & Human & No difference & Flow cytometry \\
\hline Ginis et al. [50] & Human & No difference except lower expression of CD9 & Flow cytometry \\
\hline Mamidi et al. [33] & Human & No difference & Flow cytometry \\
\hline Matsumura et al. [26] & Human & No difference & Flow cytometry \\
\hline Holubova et al. [69] & Human & No difference & Flow cytometry \\
\hline Moll et al. [38] & Human & No difference & Flow cytometry \\
\hline Al-Saqi et al. [66] & Human & No difference & Flow cytometry \\
\hline Luetzkendorf et al. [40] & Human & No difference & Flow cytometry \\
\hline Yuan et al. [52] & $\begin{array}{l}\text { Human } \\
\text { (BM-MSC } \\
\text { engineered to } \\
\text { express TRAIL) }\end{array}$ & No difference & Flow cytometry \\
\hline \multicolumn{4}{|l|}{ Other species } \\
\hline Naaldijk et al. [27] & Rat & No difference & Flow cytometry \\
\hline Davies et al. [42] & Rat & $\begin{array}{l}\text { No change in the expression of CD29 and CD73; } \\
\text { Increase in the expression of CD90, CD44 and } \\
\text { CD105 }\end{array}$ & $\begin{array}{l}\text { Flow cytometry for CD29 and CD90; RT-qPCR for } \\
\text { CD44, CD105 and CD73 }\end{array}$ \\
\hline Ock and Rho [51] & Pig & No difference & Flow cytometry \\
\hline
\end{tabular}

The main results on bone-marrow derived mesenchymal stem cell surface marker expression are presented in this table. For further details on the cryopreservation experimental details refer to either Table 1 or Additional file 2 which provide the individual freezing protocols outlined in the extracted papers alongside the concentration and passage of cells at the point of cryopreservation and the process of thawing

In the case of MSCs, studying the effect of molecular injuries and how to mitigate them is a twofold problem. Firstly, investigating molecular injuries is still a developing branch of cryobiology. In fact, immediately post-thaw cell viability has always been the most assessed cell attribute in cryopreservation studies. However, it has been shown that signs of cellular damage may take some time to manifest (cryopreservation-induced delayed-onset cell death [54]). Leading to viability and functional losses which are compounded by a lack of detection and reporting in immediate post-thaw analysis. Approaches to tackle molecular injuries, intracellular-like freezing solutions and anti-apoptotic compounds, can be deployed yet research in this area is still at an early stage [54].

Secondly, establishing and standardising potency markers and assays to characterise MSCs is still a challenge [24]. In fact, MSCs possess variability in their gene expression profiles, differentiation and expansion potential and phenotype depending on tissue origin, cell isolation and expansion procedures [56] as well as donor characteristics [57]. In 2006, the ISCT published a guideline on minimal criteria to define MSC; plastic adherence, expression of certain surface markers and lack of others and tri-lineage differentiation [47]. In 2013, these criteria were expanded to include a fourth parameter, quantification of MSC immune functional potency [58]. In 2016, the society suggested "a matrix assay approach: quantitative RNA analysis of selected gene products; flow cytometry analysis of functionally relevant surface markers and protein-based assay of the secretome" in order to fulfil the fourth criterion [59].

Currently, there are no standard markers or potency assays to typify MSCs or evaluate their post-thaw potency despite much discussion within the scientific community $[24,60]$. Therefore, research laboratories follow differing protocols which makes data evaluation complex. As both research areas (freezing molecular injuries and MSC characterisation) develop so will the methodology of evaluating MSC cryopreservation.

There are profound variabilities in the whole cryopreservation process from freezing media formulation, method of freezing and thawing and duration of storage 


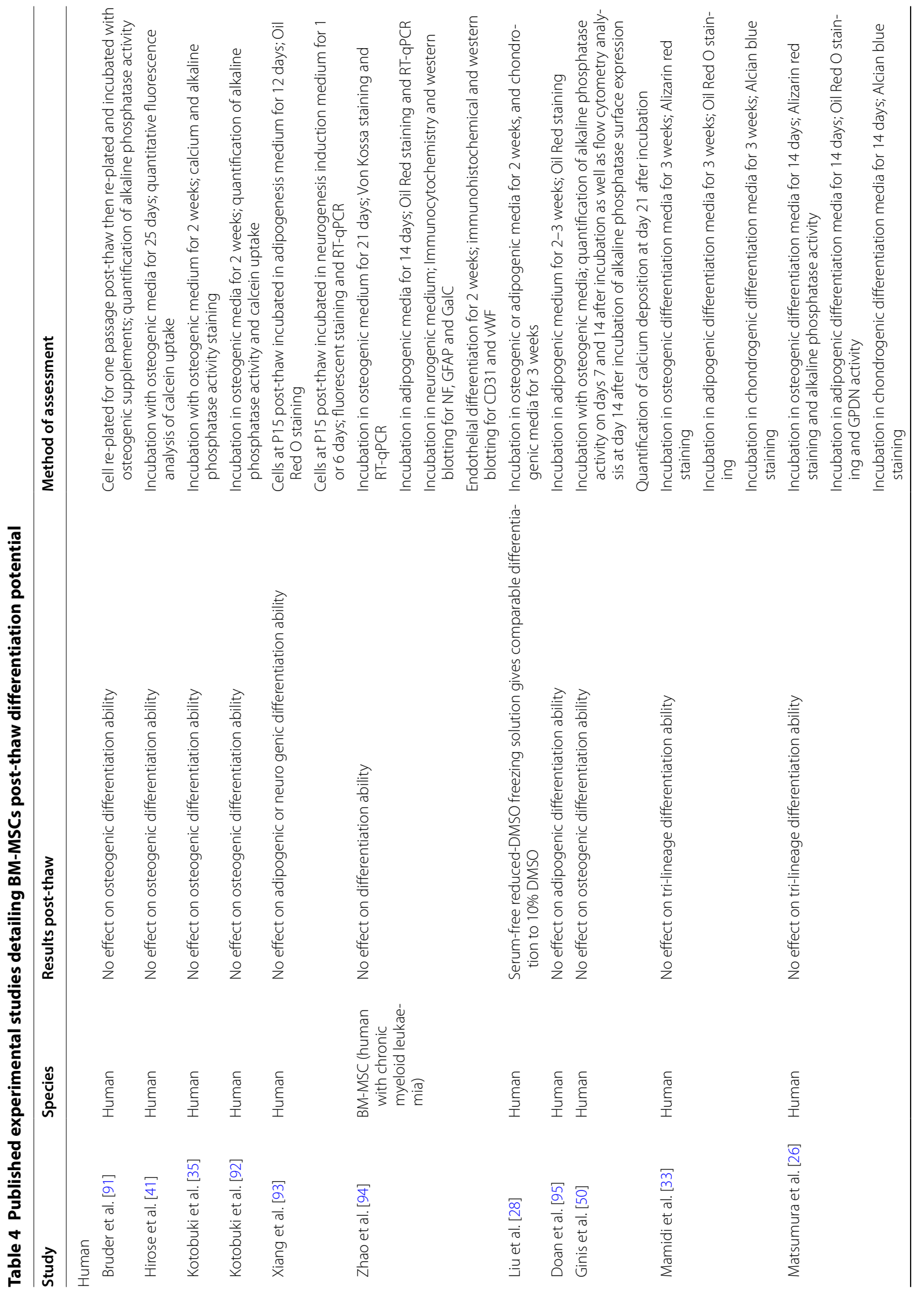




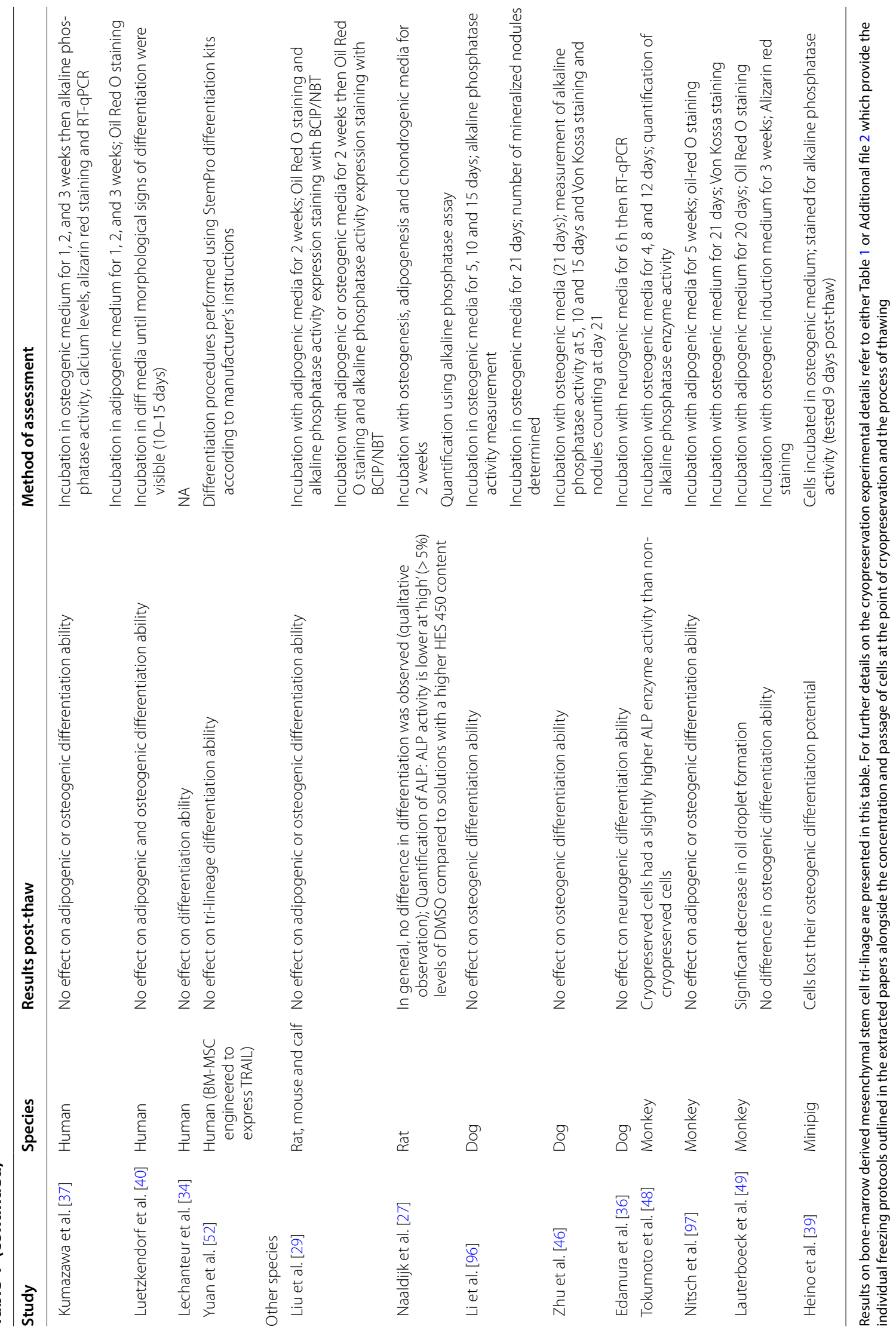




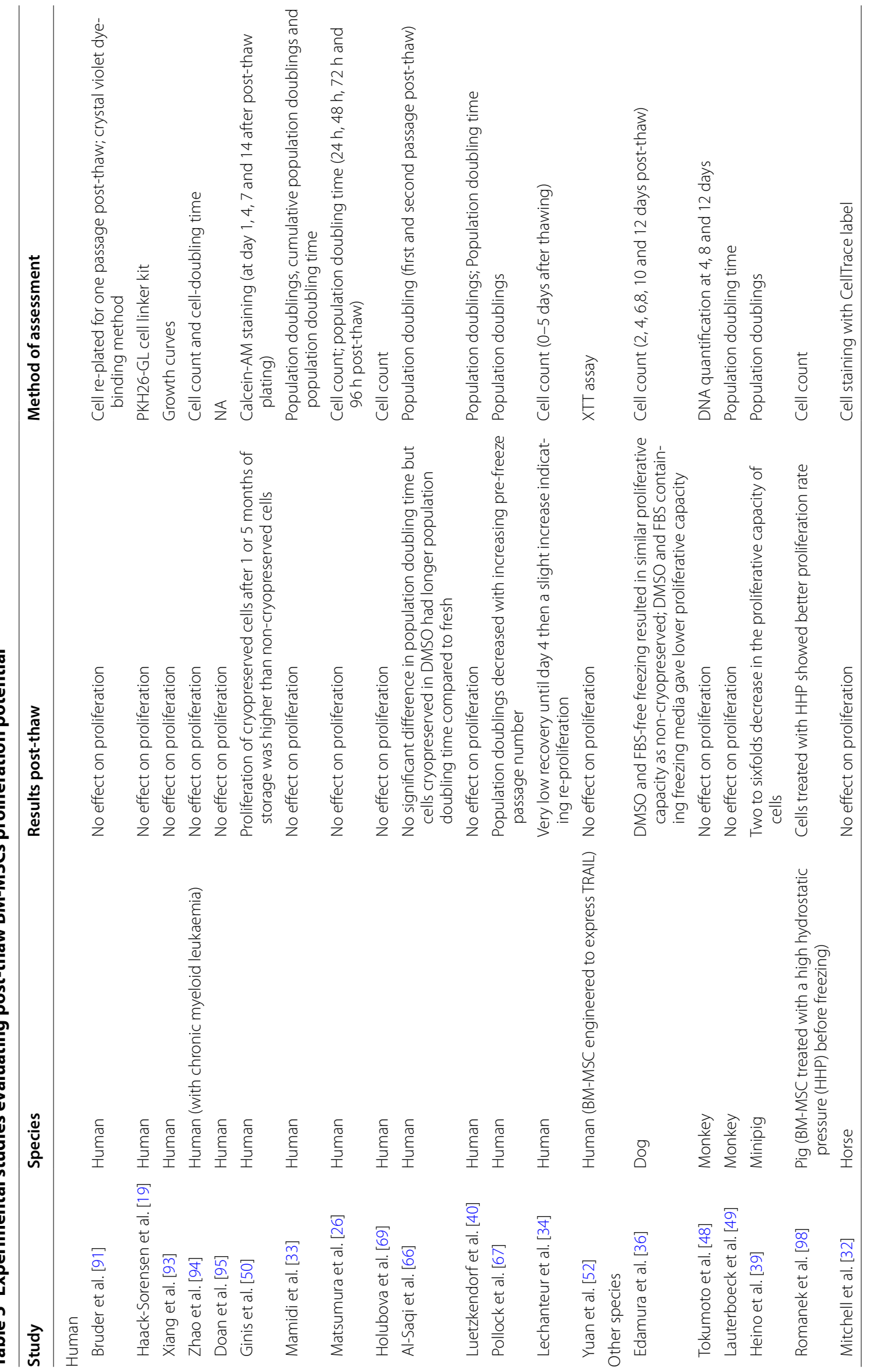




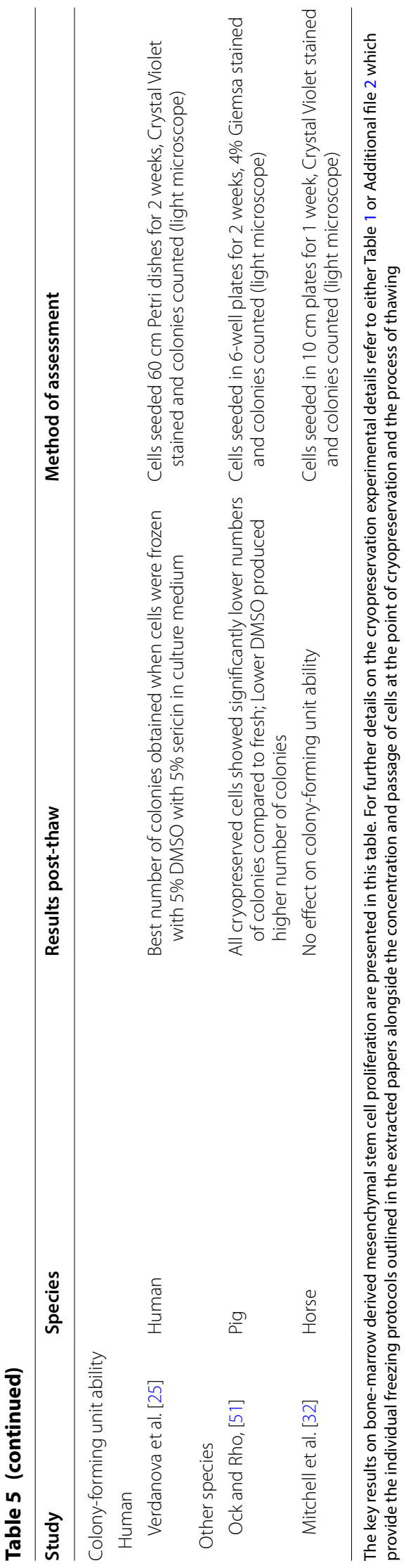


Table 6 Bone-marrow derived mesenchymal stem cell studies evaluating post-thaw metabolic activity

\begin{tabular}{|c|c|c|c|}
\hline Study & Species & Results post-thaw & Method of assessment \\
\hline \multicolumn{4}{|l|}{ Human } \\
\hline Liu et al. [28] & Human & $\begin{array}{l}\text { Reduced-DMSO freezing solution gives comparable meta- } \\
\text { bolic activity to } 10 \% \text { DMSO }\end{array}$ & AlamarBlue assay \\
\hline Chinnadurai et al. [20] & Human & No reduction in metabolic fitness & Calcium uptake; PrestoBlue reduction \\
\hline Chinnadurai et al. [68] & Human & $\begin{array}{l}\text { The addition of various concentrations of hPL (human } \\
\text { platelet lysate) did not significantly enhance MSC meta- } \\
\text { bolic activity }\end{array}$ & PrestoBlue reduction \\
\hline \multicolumn{4}{|l|}{ Other species } \\
\hline Liu et al. [29] & Rat, mouse and calf & $\begin{array}{l}\text { In general, non-cryopreserved cells showed higher overall } \\
\text { metabolic activities than the cryopreserved; Reduced } \\
\text { DMSO (5\%) with 2\% PEG, 3\% trehalose and 2\% albumin } \\
\text { give superior results to 10\% DMSO }\end{array}$ & AlamarBlue assay \\
\hline Nitsch et al. [97] & Monkey & $\begin{array}{l}\text { Lower metabolic activity for cryopreserved cells com- } \\
\text { pared with fresh; Enhnaced levels of metabolic activity } \\
\text { obtained for } 5 \% \text { and } 10 \% \text { DSMO levels }\end{array}$ & MTT assay ( 24 h, 48, 72 and 96 h post-thaw) \\
\hline Lauterboeck et al. [49] & Monkey & $\begin{array}{l}\text { Cells' metabolic activity was impaired up until } 48 \mathrm{~h} \text { post- } \\
\text { thaw; Partial recovery at } 72 \mathrm{~h} \text { and full recovery observed } \\
\text { at } 96 \mathrm{~h}\end{array}$ & MTT assay (24 h, 48, 72 and 96 h post-thaw) \\
\hline
\end{tabular}

The key results on bone-marrow derived mesenchymal stem cell metabolic activity after cryopreservation are presented in this table. For further details on the cryopreservation experimental details refer to either Table 1 or Additional file 2 which provide the individual freezing protocols outlined in the extracted papers alongside the concentration and passage of cells at the point of cryopreservation and the process of thawing

to passage number and cell concentration at freezing. However, despite all these variabilities and all the species included, there was evidence showing that four BMMSCs attributes are stable and unaffected by the stresses imposed by freezing and thawing and these are: cell morphology, marker expression, proliferation potential and tri-lineage differentiation capability (although chondrogenesis was only assessed by five independent studies). The four other attributes viability, attachment and migration, genomic stability and paracrine function were governed by either conflicting results or by low assessment frequency.

All studies have employed a strategy to evade freezing and thawing physical damage. Freezing BM-MSCs at a slow cooling rate (at least at the start of the cooling process) and thawing at a high rate was followed by almost all the studies in this review. In terms of media formulation, DMSO remains the most commonly used cryoprotectant to protect BM-MSCs (used by $90 \%$ of studies analysed). However, DMSO is associated with adverse effects such as cardiac side effects $[61,62]$ and severe neurotoxicity $[63,64]$ when infused in patients. Consequently, reducing or eliminating DMSO, depending on clinical outcome, may become a requisite.

Mixing other potential cryoprotectants with DMSO at percentages $<10 \%$ indicates that this traditionally held protectant and percentage can both be altered [26-28]. This is an interesting result which indicates that eliminating DMSO from freezing solution is a viable option and is worthy of further evaluation based on a wider postthaw MSC functional characteristics. Another important aspect of MSC cryopreservation is the fact that FBS is commonly added to freezing solutions for its benefits to stabilise the cell membrane and adjust cell osmotic pressure [65]. The main issue in using FBS is that it is animal-derived and may cause a xenogenic reaction if infused in patients [65]. Cryopreserving hBM-MSCs in xeno-free media was assessed across 13 studies [18, 26, 34, 38, 40, 48-50, 52, 66-69]. Verdanova et al. reported using Sericin (a protein derived from silkworm cocoon) as an FBS substitute for preserving human BM-MSCs [25]. The possibility of overlapping xeno-free and low or no DMSO exists in one study where monkey BM-MSCs were successfully frozen in xeno-free solution composed of methylcellulose, poloxamer, $\alpha$-tocopherol and only $2.5 \%$ DMSO [49]. Such a freezing solution would be ideal because it is not only xeno-free but also contains a very low DMSO concentration.

Cell concentration at freezing and the duration of storage are not well studied, and it is not well documented if it plays a role in the performance of the end-product. The only study which tested cell viability after freezing at three different cell concentrations found no significant variation [52]. In regard to duration of storage, of note is the study where BM-MSCs were stored for more than 10 years without losing multipotency [37]. This could well be a suggestion that once cells enter a quiescent state, its duration is not of great significance. 
Table 7 The induction of apoptosis in post-thaw BM-MSCs

\begin{tabular}{|c|c|c|c|}
\hline Study & Species & Results post-thaw & Method of assessment \\
\hline \multicolumn{4}{|l|}{ Apoptosis } \\
\hline \multicolumn{4}{|l|}{ Human } \\
\hline Liu et al. [28] & Human & $\begin{array}{l}\text { Serum-free reduced-DMSO freezing solution } \\
\text { gives comparable apoptotic percentage to } \\
\text { 10\% DMSO }\end{array}$ & Flow cytometry \\
\hline Ginis et al. [50] & Human & $\begin{array}{l}\text { Lower percentage of apoptotic cells obtained } \\
\text { with Annexin V and Hoechst staining com- } \\
\text { pared to caspase } 3 \text { assay: using caspase } 3 \text {, the } \\
\text { percentage of apoptotic cells was between } \\
13 \text { and } 17 \% \text { for CryStor media compared to } \\
3 \% \text { for conventional freezing media }\end{array}$ & $\begin{array}{l}\text { Flow cytometry-Annexin V, Hoechst, Caspase } \\
3 \text { activity }\end{array}$ \\
\hline Chinnadurai et al. [20] & Human & $\begin{array}{l}\text { Higher percentage of apoptotic cells in cryo- } \\
\text { preserved MSC than live MSC }\end{array}$ & Flow cytometry \\
\hline Moll et al. [38] & Human & $\begin{array}{l}\text { Apoptosis increased by cryopreservation when } \\
\text { exposed to human serum }\end{array}$ & Flow cytometry-Annexin V, PI staining \\
\hline \multicolumn{4}{|l|}{ Other species } \\
\hline Ock and Rho [51] & Pig & $\begin{array}{l}\text { Bak and Bcl2 gene expression in cryopreserved } \\
\text { cells was higher than fresh at } 3 \text { h post-thaw: } \\
\text { Bak and Bcl } 2 \text { gene expression in cryopre- } \\
\text { served cells was comparable to fresh after } \\
\text { culturing thawed cells up to } 90 \% \text { confluence: } \\
\text { Bcl } 2 \text { antigen expression level was compara- } \\
\text { ble to fresh after culturing thawed cells up to } \\
90 \% \text { confluence }\end{array}$ & $\begin{array}{l}\text { RT-qPCR for Bak and Bcl2: Flow cytometry; } \mathrm{BCl} 2 \\
\text { antigen }\end{array}$ \\
\hline Romanek et al. [98] & $\begin{array}{l}\text { Pig (BM-MSC treated } \\
\text { with HHP before } \\
\text { freezing) }\end{array}$ & $\begin{array}{l}\text { No significant difference between control } \\
\text { (without HHP) and cells subjected to HHP } \\
\text { pre-freeze }\end{array}$ & $\begin{array}{l}\text { Flow cytometry-Annexin V: Fluorescence } \\
\text { microscopy }\end{array}$ \\
\hline \multicolumn{4}{|l|}{ Senescence } \\
\hline \multicolumn{4}{|l|}{ Human } \\
\hline Mamidi et al. [33] & Human & No difference in the level of senescent cells & B-galactosidase assay \\
\hline Al-Saqi et al. [66] & Human & $\begin{array}{l}\text { There were signs of senescence (but could } \\
\text { be due to culture medium rather than cryo- } \\
\text { preservation medium) }\end{array}$ & $\begin{array}{l}\text { B-galactosidase assay (analysed } 2 \text { passages after } \\
\text { cryopreservation) }\end{array}$ \\
\hline Pollock et al. [67] & Human & $\begin{array}{l}\text { Immediate pre-freeze senescence levels show } \\
\text { similar trends but higher levels compared to } \\
\text { pre-freeze At } 48 \text { h post-thaw, level of senes- } \\
\text { cent cells dropped significantly comparing to } \\
\text { immediately post-thaw }\end{array}$ & Beta-glo assay \\
\hline
\end{tabular}

The key results on bone-marrow derived mesenchymal stem cell apoptotic activity post-thaw are presented in this table. For further details on the cryopreservation experimental details refer to either Table 1 or Additional file 2 which provide the individual freezing protocols outlined in the extracted papers alongside the concentration and passage of cells at the point of cryopreservation and the process of thawing

The evaluation of the cryopreservation process is certainly an existing challenge. Our understanding of the biology of MSCs is evolving and so are the possibilities of the application of these cells in the medical field. Yet, as stated recently "Significant challenge remains the development of a relevant potency assay" [34]. These assays must be quick, easy and should not require trained personnel if they are to be used to release each cell batch in a clinical setting and if they are to fit with operation theatre logistics (thawing, testing and infusing within a couple of hours). In theory, potency assays could be therapy-specific and must indicate cell functionality; in other words, "mechanism(s) of action"
[70]. How much these assays correlate with the in vivo niche is also of great importance. In addition, "the assay should be able to differentiate between sufficiently potent and sub-potent batches, a (semi-)quantitative assay is required" [56]. This thawing-infusing scenario would be realistic only if cryopreservation methods have improved to give an optimal product immediately after thawing.

Cell morphology (shape and size) can give indication on cell's health as well as whether they have committed to differentiate or not. The absence of change in BM-MSCs morphology after cryopreservation can indicate that the freeze-thaw process does not cause differentiation or 
Table 8 Bone-marrow derived Mesenchymal Stem Cell studies evaluating cellular attachment post-thaw

\begin{tabular}{|c|c|c|c|}
\hline Study & Species & Results post-thaw & Method of assessment \\
\hline \multicolumn{4}{|l|}{ Attachment } \\
\hline \multicolumn{4}{|l|}{ Human } \\
\hline Heng [30] & Human & $\begin{array}{l}\text { Level of adherent cells was } 39.8 \pm 0.9 \% \text {; } \\
\text { increased by approx. } 10 \% \text { with Y-27632 }\end{array}$ & MTT assay performed $24 \mathrm{~h}$ post-thawing \\
\hline Chinnadurai et al. [20] & Human & $\begin{array}{l}40 \% \text { reduction in adhesion to fibronectin; } 80 \% \\
\text { reduction in adhesion to endothelial cells; No } \\
\text { reduction in the surface expression of adhe- } \\
\text { sion molecules }\end{array}$ & $\begin{array}{l}\text { After } 2 \mathrm{~h} \text { in static and } 1 \mathrm{~h} \text { in vascular flow condi- } \\
\text { tions using microscopy (light); Flow cytometry } \\
\text { for adhesion molecules }\end{array}$ \\
\hline \multicolumn{4}{|l|}{ Other species } \\
\hline Li et al. [96] & Dog & $\begin{array}{l}\text { Decreased adhesion capacity post-thaw; } \\
\text { recovery of adhesion capacity after culturing } \\
\text { for several passages }\end{array}$ & $\begin{array}{l}\text { Adherent cell count (hemo-cytometer) at 4, 8, } 12 \\
\text { and } 24 \text { h post-thaw }\end{array}$ \\
\hline Tokumoto et al. [48] & Monkey & $\begin{array}{l}\text { Limited influence of cryopreservation on cell } \\
\text { adhesion capabilities }\end{array}$ & Adherent cell count (hemo-cytometer) \\
\hline \multicolumn{4}{|l|}{ Migration } \\
\hline \multicolumn{4}{|l|}{ Human } \\
\hline Yuan et al. [52] & $\begin{array}{l}\text { Human (BM-MSC engi- } \\
\text { neered to express } \\
\text { TRAIL) }\end{array}$ & No effect on migration potential & Trans-well plates \\
\hline
\end{tabular}

The effects of cryopreservation on bone-marrow derived mesenchymal stem cell attachment are presented in this table. For further details on the cryopreservation experimental details refer to either Table 1 or Additional file 2 which provide the individual freezing protocols outlined in the extracted papers alongside the concentration and passage of cells at the point of cryopreservation and the process of thawing

change in cell phenotype. This conclusion is further evidenced by the absence of effect of cryopreservation on BM-MSCs marker expression post-thaw.

No such firm conclusion can be drawn when it comes to viability. This is of real importance given that viability is one of the release criteria for cell therapies. In fact, viability has and will always be the primary indicator on cryopreservation success. It is an easy, cheap and fast measurement but is has some limitations. The various methods used across labs to measure viability and the lack of a unified reporting structure makes it hard to compare results. Although $\geq 90 \%$ viability for fresh MSC product and $\geq 70 \%$ viability for cryopreserved MSC product are generally considered the benchmark for clinical application [57], different labs report viability maintenance or loss of viability based on comparison with pre-freeze viability or on comparison with freezing with 10\% DMSO (refer Table 1). In addition, the common measurement time-point, only immediately post-thaw could be misleading due to the late manifestation of the effect of current cryopreservation protocols on cells.

In fact, the initiation of apoptotic events is evident according to the data in Table 7. Despite the importance of this cryopreservation-related cell death, it is surprising how limited the investigation of this molecular pathway in thawed BM-MSCs is and the strategies to reduce it are. Only two studies utilized strategies to prevent post-thaw apoptosis (molecular injury). The addition of Rho-associated kinase inhibitor Y-27632 in the freezing medium and in the post-thaw culture medium did not improve hBM-MSCs viability immediately but recorded enhanced recoveries at 24-h post-thaw [30]. However, the addition of Caspase inhibitor z-VAD-fmk in the freezing media did not prove to be beneficial for equine, ovine and rodent BM-MSCs as assessed by viability immediately, at 24 and $48 \mathrm{~h}$ post-thaw [31].

An expert workshop on preservation and stability of cell therapy products was held in May 2015 [71]. Assessing post-thaw viability was one of the topics discussed and the limitations/conflicts mentioned above were identified. The group advised that assessing cell viability post-thaw should "go beyond simple enumeration of cell numbers to facilitate a greater understanding of the cell system in question". In addition, the group realised the need for more advanced and accurate methods to assess cell viability that can be linked to cell function [71].

Interestingly, impaired cell metabolism can be closely associated with apoptotic pathways through the Bcl-2 family proteins which initiates apoptosis in metabolically stressed cells through utilization of autophagy as a nutrient source before ultimately undergoing necrosis $[72,73]$. From the data presented in Table 6 some impairment of BM-MSCs metabolic activity post-thaw is evident. Therefore, a link between defective metabolic activity in thawed BM-MSCs and a higher level of apoptosis postthaw could be postulated. This may indicate new pathways to mitigate against these post-thaw phenomena. 
Table 9 Published experimental studies detailing BM-MSCs post-thaw paracrine function

\begin{tabular}{|c|c|c|c|}
\hline Study & Species & Results post-thaw & Method of assessment \\
\hline \multicolumn{4}{|l|}{ Immunomodulatory potential } \\
\hline \multicolumn{4}{|l|}{ Human } \\
\hline Zhao et al. [94] & $\begin{array}{l}\text { Human (with chronic } \\
\text { myeloid leukae- } \\
\text { mia) }\end{array}$ & No effect on immunomodulatory potential & Mixed leukocyte reaction inc. T-cell proliferation \\
\hline François et al. [45] & Human & $\begin{array}{l}\text { Impaired inhibition of proliferation of activated } \\
\text { T cells; low IDO protein expression in } \\
\text { response to INF- } \gamma \text { stimulation; up-regulation } \\
\text { of heat shock proteins }\end{array}$ & $\begin{array}{l}\text { T-cell proliferation assay (CD3/CD28); Western } \\
\text { blot IDO; RT-qPCR IDO, CCL2, IL-6 }\end{array}$ \\
\hline Holubova et al. [69] & Human & No effect on immunomodulatory potential & T-cell proliferation (PHA) \\
\hline Moll et al. [38] & Human & Impaired immunomodulatory properties & $\begin{array}{l}\text { RT-qPCR IDO, IL-6; Western blot IDO; Instant } \\
\text { blood mediated inflammatory reaction } \\
\text { (IBMIR) }\end{array}$ \\
\hline Luetzkendorf et al. [40] & Human & No effect on immunomodulatory potential & Co-culture with PBMC; T-cell proliferation (PHA) \\
\hline Chinnadurai et al. [68] & Human & $\begin{array}{l}\text { Freeze-thawing attenuates immunosuppres- } \\
\text { sive properties of human MSC independent } \\
\text { of freezing methods or freezing media; } \\
\text { Thawed MSC can suppress T-cell prolif- } \\
\text { eration in the absence of cell contact; IFNy } \\
\text { pre-licensing prior to cryopreservation } \\
\text { enhances thawed MSC's immunosuppressive } \\
\text { properties }\end{array}$ & $\begin{array}{l}\text { Co-culture with PBMC; T-cell proliferation (CD3/ } \\
\text { CD28 \& SEB); RT-qPCR IDO, Hsp }\end{array}$ \\
\hline Gramlich et al. [18] & Human & No effect on immunomodulatory potential & $\begin{array}{l}\text { Co-culture with PBMC; T-cell proliferation (CD3/ } \\
\text { CD28); IDO activity assay (kynurenine) }\end{array}$ \\
\hline Lechanteur et al. [34] & Human & Impaired immunomodulatory properties & $\begin{array}{l}\text { Co-culture with PBMC; T-cell proliferation (CD3/ } \\
\text { CD28); IDO activity assay (kynurenine) }\end{array}$ \\
\hline \multicolumn{4}{|l|}{ Angiogenesis potential } \\
\hline \multicolumn{4}{|l|}{ Human } \\
\hline Haack-Sorensen et al. [19] & Human & $\begin{array}{l}\text { No effect on the capacity of MSC to differenti- } \\
\text { ate into endothelial cells; Retained VEGF } \\
\text { responsiveness }\end{array}$ & In vitro angiogenesis; RT-qPCR, KDR, vWF, INSIG \\
\hline \multicolumn{4}{|l|}{ Growth factor secretion } \\
\hline \multicolumn{4}{|l|}{ Human } \\
\hline Gramlich et al. [18] & Human & $\begin{array}{l}\text { Small changes in growth factor secretion } \\
\text { between fresh and cryopreserved cells }\end{array}$ & Human antibody-mediated growth factor array \\
\hline
\end{tabular}

Summary of the effects of cryopreservation on bone-marrow derived mesenchymal stem cell paracrine function are presented in this table. For further details on the cryopreservation experimental details refer to either Table 1 or Additional file 2 which provide the individual freezing protocols outlined in the extracted papers alongside the concentration and passage of cells at the point of cryopreservation and the process of thawing

More research is needed if cells are to be thawed and immediately infused in patients. Infusing apoptotic cells will hinder MSCs therapeutic benefits. Moreover, it is vital that therapeutic cells emerge potent from freezing to be capable to survive in a damaged tissue where they will encounter a hostile environment with mechanical, hypoxia and nutritional stresses, the host immune response and inflammation. These factors are known to cause a huge loss in MSC viability after transplantation as well as poor engraftment [74]. According to Table 8 , frozen cells have lower adherence capability. One study has tried to examine this post-thaw phenomena in more detail lending evidence to a disruption of F-actin polymerization rather than shedding of surface adhesion receptors [20]. Advancing our knowledge in this area will help manufacture clinical MSCs with improved regenerative engraftment, although the concept of MSCs proliferating, differentiating and engrafting in host tissue as their primary therapeutic modality has been recently challenged [75].

Generally, it can be said that cryopreservation does not affect BM-MSCs proliferative capacity (Table 5). However, intriguing evidence is presented by Ginis et al. [50] on the potential cell selection that the cryopreservation process may enforce. In this study, BMMSCs post-thaw proliferation potential was higher than that at pre-freeze. The authors justified their results as "selection of stronger cells after cryopreservation" and suggested that their results should "alarm a scientific community". This same theory has also been mentioned 
by Baust et al. [76] who stated, "unstudied but of concern is the potential for the preservation process to select for increased resistance to preservation stresses".

From Table 5, it can be concluded that there is a strong agreement that cryopreservation does not affect BMMSCs differentiation potential. This conclusion is of value to fulfil one of the 2006 ISCT criteria for MSCs. However, differentiation potential may become less important for cell therapy. For example, in heart disease, MSCs' initial mechanism of regeneration was outlined as differentiation into cardiomyocytes and incorporation into the host tissue. Recently, this outline has been updated to shed a light on a more effective regeneration mechanism and that is their associated paracrine signalling [75]. In fact, paracrine signalling is not confined to cardiac regeneration but is now generally considered as the MSCs main mode of action. Caplan [77] suggested that it is "time to change the name" of MSCs to "Medicinal Signalling Cells" in order to better describe the secretion of trophic factors. According to Gonzalez et al. [78] " $80 \%$ of the therapeutic effect of stem cells is attributed to paracrine actions".

The MSCs secretome is composed of growth factors and cytokines either soluble or engulfed in exosomes and/or vesicles $[75,79,80]$. MSC paracrine signalling is described as exerting plethora of effects including induction of angiogenesis, regulation of immune response and inflammation, modulation of cell differentiation and proliferation, extracellular matrix formation, neuroprotective and neurotrophic effects, anti-apoptotic, anti-tumour and anti-microbial activities [81, 82]. Yet despite such a compelling list of activities no comprehensive evaluation of the MSC secretome, and or its cell-free utility, has been conducted [83]. Data on the BM-MSCs secretome upon thawing is very limited and so is the data on angiogenic potential. There are only two studies which concluded that no effect of cryopreservation was observed (Table 9).

At an injury site, MSC contribute to the creation of an anti-inflammatory environment by suppressing the activation and proliferation of pro-inflammatory cells and promoting anti-inflammatory cells [84]. This modulation of both the innate and adaptive immune system can be accomplished in two ways: via cell-cell interaction and cell-cell communication through an array of soluble factors including indoleamine 2,3-dioxygenase (IDO) and/ or extracellular vesicles [85]. These characteristics were the main contributors in raising the MSC profile as therapeutically valuable. As discussed above, MSC immune function has now become an essential indicator on MSC function. In view of this, it is expected that more studies on MSC immunomodulatory properties, and assays to evaluate them will emerge. Recently, Chinnadurai et al.

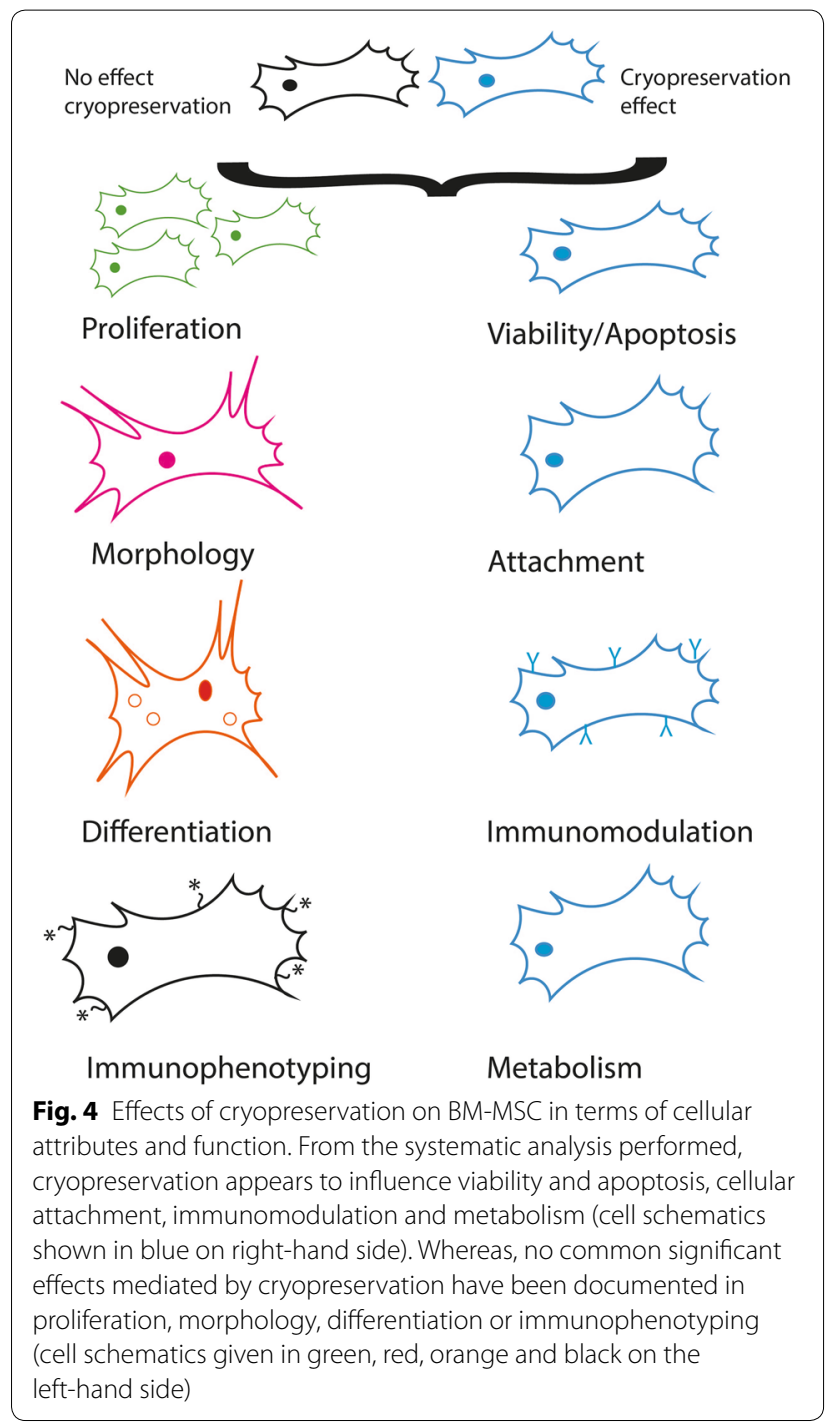

[86] tested BM-MSCs potency using a matrix approach and concluded that cryopreservation negatively affects cells' secretome with $\mathrm{T}$ cell proliferation. According to Table 9, eight studies assessed BM-MSCs immune function post-thaw with a balance of four concluding damaging effect and four concluding no effect.

\section{Conclusion}

This systematic review has highlighted areas of agreement and deviation that currently exist around BMMSCs properties and functions after cryopreservation (Fig. 4).

With MSC-based therapies expected to offer treatment choices for several conditions and diseases that are currently incurable and presently no MSC drug yet approved by the FDA the biological community must work towards reproducible and reliable data sets to achieve regulatory accepted 
drug status. With cryopreservation effects being fully identified and assessed in terms of therapeutic evaluation.

Continuing variance in our scientific approaches facilitates unapproved therapies and stem cell tourism [87, 88]; leading both the FDA and ISCT to urge both caution for individuals and request enhanced rigor, reproducibility and visibility from the scientific community $[59,89,90]$. "Successful new therapies come at a considerable cost that cannot easily be sustained without evaluation and guidance" [89].

This review has been limited to one tissue source and that is bone marrow, yet we know that MSCs can be isolated from almost all tissues especially adipose and umbilical cord [17]. Including more tissue sources was beyond the scope of this review yet it is important to document the impact of cryopreservation on those MSC sources also.

\section{Supplementary information}

Supplementary information accompanies this paper at https://doi. org/10.1186/s12967-019-02136-7.

Additional file 1. Table of cellular attribute data from studies extracted for the systematic review. It is a grid identifying which cell attributes each of the forty-one studies assessed. Of note each of the 41 studies may appear more than once depending on the attributes they assessed. Where a study undertook an assessment of a cellular attribute a cross is placed in the grid. Studies are arranged by species: human [chronologically and then alphabetically] and animals from most to least frequent species [chronologically and then alphabetically]). Column headers: Morphology; Morph. Viability; Via. Immunophenotyping; IP. Differentiation; Diff. Colony forming unit frequency; CFUF. Growth; Total growth. Metabolism; Met. Apoptosis; Apo. Attachment; Attach. Immunomodulation; Immuno. Paracrine; Para. Angiogenesis; Angio. Migration; Migr.

Additional file 2. Tabulated information relating to the freezing details extracted from the relevant studies. It shows the details of the individual freezing protocols outlined in the 41 retained studies. The method of freezing is given in detail alongside the species information, the concentration and passage of cells at the point of cryopreservation and the process of thawing. These details are common to the results tables (Tables 1, 2, 3, 4, 5, 6, 7, 8, 9).

\section{Abbreviations}

7-AAD: 7-aminoactinomycin D; a-MEM: alpha modified eagle medium; ADMEM: advanced Dulbecco's medium eagle media; COOH-PLLs: carboxylated poly-L-lysine; DMEM: Dulbecco's medium eagle media; DMEM/F12: 1:1 mixture of Dulbecco's Medium and Ham's F-12 medium; DMSO: dimethylsulfoxide; EMEA: DMEM, low glucose with HEPES $1 x$; FBS: fetal bovine serum; FCS: fetal calf serum; H: hour(s); hPL: human platelet lysate; IMDM: Iscove's modified Dulbecco's medium; INF- $\gamma$ : interferon-gamma; MEM: modified eagle medium; microM: micromolar; Min: minute(s); NA: not available; P: passage; PEG: polyethylene glycol; PHA: phytohemagglutinin; pHPL: pooled human platelet lysate; PI: propidium iodide; SEB: Staphylococcal enterotoxin B.

\section{Acknowledgements}

None.

\section{Authors' contributions}

ECA and SB jointly contributed to the conception of the manuscript. Searches and generation of the manuscript were carried out by SB. ECA contributed throughout the preparation and edited the manuscript. All authors read and approved the final manuscript.
Funding

Financial support from the Engineering and Physical Research Council (EP/ L015072/1), UK and SSEHS, Loughborough University is acknowledged.

\section{Availability of data and materials}

All data generated by this systematic search are included in this published article.

Ethics approval and consent to participate

Not applicable.

\section{Consent for publication}

Not applicable.

\section{Competing interests}

The authors declare that they have no competing interests.

\section{Author details}

1 School of Sport, Exercise and Health Sciences, Loughborough University, Loughborough, Leicestershire LE11 3TU, UK. ${ }^{2}$ Centre for Biological Engineering, Loughborough University, Loughborough, Leicestershire LE11 3TU, UK.

Received: 6 July 2019 Accepted: 12 November 2019

Published online: 29 November 2019

\section{References}

1. Friedenstein AJ, Chailakhjan RK, Lalykin KS. The development of fibroblast colonies in marrow and spleen cells. Cell Tissue Kinet. 1970;3:393-403.

2. Friedenstein AJ, Gorskaja JF, Kulagina NN. Fibroblast precursors in normal and irradiated mouse hematopoietic organs. Exp Hematol. 1976;4(5):267-74.

3. Prockop D. Marrow stromal cells as stem cells for nonhematopoietic tissues. Science. 1997;276(5309):71-4.

4. Chamberlain G, Fox J, Ashton B, Middleton J. Concise review: mesenchymal stem cells: their phenotype, differentiation capacity, immunological features, and potential for homing. Stem Cells. 2007;25(11):2739-49.

5. Afanasyev BV, Elstner EE, Zander ARAJ. friedenstein, founder of the mesenchymal stem cell concept. Cell Ther Transplant. 2009;1(3):35-8.

6. Nombela-Arrieta C, Ritz J, Silberstein LE. The elusive nature and function of mesenchymal stem cells. Nat Rev Mol Cell Biol. 2011;12:126-31.

7. Owen M. Marrow stromal stem cells. J Cell Sci. 1988;10:63-76.

8. Caplan Al. Mesenchymal stem cells. J Orthop Res. 1991;9(5):641-50.

9. Mizukami A, Swiech K. Mesenchymal stromal cells: from discovery to manufacturing and commercialization. Stem Cells Int. 2018. https://doi. org/10.1155/2018/4083921.

10. Lazarus HM, Haynesworth SE, Gerson SL, Rosenthal NS, Caplan Al. Ex vivo expansion and subsequent infusion of human bone marrow-derived stromal progenitor cells (mesenchymal progenitor cells): implications for therapeutic use. Bone Marrow Transplant. 1995;16(4):557-64.

11. Lotfinejad P, Shamsasenjan K, Movassaghpour A, Majidi J, Baradaran B. Immunomodulatory nature and site specific mesenchymal stem cells: a hope in cell therapy. Adv Pharm Bull. 2014;4(1):5-13.

12. Salem HK, Thiemermann C. Mesenchymal stromal cells: current understanding and clinical status. Stem Cells. 2010;28(3):585-96.

13. Abazari A, Hawkins BJ, Clarke DM, Mathew AJ. Biopreservation best practices: a cornerstone in the supply chain of cell-based therapies-MSC model case study. Cell Gene Ther Insights. 2017;3(10):853-71.

14. Woods EJ, Thirumala S, Badhe-Buchanan SS, Clarke D, Mathew AJ. Off the shelf cellular therapeutics: factors to consider during cryopreservation and storage of human cells for clinical use. Cytotherapy. 2016;18(6):697-711.

15. Mendicino M, Bailey AM, Wonnacott K, Puri RK, Bauer SR. MSC-based product characterization for clinical trials: an FDA perspective. Cell Stem Cell. 2014;14:141-5.

16. Coopman K. Large-scale compatible methods for the preservation of human embryonic stem cells: current perspectives. Biotechnol Prog. 2011;27(6):1511-21. 
17. Marquez-Curtis LA, Janowska-Wieczorek A, McGann LE, Elliott JAW. Mes enchymal stromal cells derived from various tissues: biological, clinical and cryopreservation aspects. Cryobiology. 2015;71:181-97.

18. Gramlich OW, Burand AJ, Brown AJ, Deutsch RJ, Kuehn MH, Ankrum JA. Cryopreserved mesenchymal stromal cells maintain potency in a retinal ischemia/reperfusion injury model: toward an off-the-shelf therapy. Sci Rep. 2016;6:26463.

19. Haack-Sorensen M, Bindslev L, Mortensen S, Friis T, Kastrup J. The influence of freezing and storage on the characteristics and functions of human mesenchymal stromal cells isolated for clinical use. Cytotherapy. 2007;9(4):328-37.

20. Chinnadurai R, Garcia MA, Sakurai Y, Lam WA, Kirk AD, Galipeau J, et al. Actin cytoskeletal disruption following cryopreservation alters the biodistribution of human mesenchymal stromal cells in vivo. Stem Cell Rep. 2014;3(1):60-72.

21. Moll G, Geißler S, Catar R, Ignatowicz L, Hoogduijn MJ, Strunk D, et al. Cryopreserved or fresh mesenchymal stromal cells: only a matter of taste or key to unleash the full clinical potential of MSC therapy? Advances in experimental medicine and biology. Cham: Springer; 2016. p. 77-98.

22. Galipeau J, Krampera M. The challenge of defining mesenchymal stromal cell potency assays and their potential use as release criteria. Cytotherapy. 2015;17(2):125-7.

23. Trento C, Bernardo ME, Nagler A, et al. Manufacturing mesenchymal stromal cells for the treatment of graft-versus-host disease: a survey among centers affiliated with the European Society for Blood and Marrow Transplantation. Biol Blood Marrow Transplant. 2018;24(11):2365-70.

24. Bahsoun S, Coopman K, Forsyth NR, Akam EC. The role of dissolved oxygen levels on human mesenchymal stem cell culture success, regulatory compliance, and therapeutic potential. Stem Cells Dev. 2018;27(19):1303-21.

25. Verdanova M, Pytlik R, Kalbacova MH. Evaluation of sericin as a fetal bovine serum-replacing cryoprotectant during freezing of human mesenchymal stromal cells and human osteoblast-like cells. Biopreserv Biobank. 2014;12(2):99-105.

26. Matsumura K, Hayashi F, Nagashima T, Hyon SH. Long-term cryopreservation of human mesenchymal stem cells using carboxylated poly-L-lysine without the addition of proteins or dimethyl sulfoxide. J Biomater Sci Polym Ed. 2013;24(12):1484-97.

27. Naaldijk Y, Staude M, Fedorova V, Stolzing A. Effect of different freezing rates during cryopreservation of rat mesenchymal stem cells using combinations of hydroxyethyl starch and dimethylsulfoxide. BMC Biotechnol. 2012;12(1):49

28. Liu Y, Xu X, Ma X, Martin-Rendon E, Watt S, Cui Z. Cryopreservation of human bone marrow-derived mesenchymal stem cells with reduced dimethylsulfoxide and well-defined freezing solutions. Biotechnol Prog. 2010;26(6):1635-43.

29. Liu Y, Xu X, Xuehu M, Liu J, Cui Z. Effect of various freezing solutions on cryopreservation of mesenchymal stem cells from different animal species. Cryo-Letters. 2011;32(5):425-35.

30. Heng BC. Effect of Rho-associated kinase (ROCK) inhibitor Y-27632 on the post-thaw viability of cryopreserved human bone marrow-derived mesenchymal stem cells. Tissue Cell. 2009;41(5):376-80.

31. Renzi S, Lombardo T, Dotti S, Dessi SS, De Blasio P, Ferrari M. Mesenchymal stromal cell cryopreservation. Biopreserv Biobank. 2012;10(3):276-81.

32. Mitchell A, Rivas KA, Smith R, Watts AE. Cryopreservation of equine mesenchymal stem cells in 95\% autologous serum and 5\% DMSO does not alter post-thaw growth or morphology in vitro compared to fetal bovine serum or allogeneic serum at 20 or $95 \%$ and DMSO at 10 or 5\%. Stem Cell Res Ther. 2015;6(1):231.

33. Mamidi MK, Nathan KG, Singh G, Thrichelvam ST, Mohd Yusof NAN, Fakharuzi NA, et al. Comparative cellular and molecular analyses of pooled bone marrow multipotent mesenchymal stromal cells during continuous passaging and after successive cryopreservation. J Cell Biochem. 2012;113(3):3153-64.

34. Lechanteur C, Briquet A, Giet O, Delloye O, Baudoux E, Beguin Y. Clinicalscale expansion of mesenchymal stromal cells: a large banking experience. J Transl Med. 2016;14(1):145.

35. Kotobuki N, Hirose M, Takakura Y, Ohgushi H. Cultured autologous human cells for hard tissue regeneration: preparation and characterization of mesenchymal stem cells from bone marrow. Artif Organs. 2004:28(1):33-9.
36. Edamura K, Nakano R, Fujimoto K, Teshima K, Asano K, Tanaka S. Effects of cryopreservation on the cell viability, proliferative capacity and neuronal differentiation potential of canine bone marrow stromal cells. J Vet Med Sci. 2014;76(4):573-7.

37. Kumazawa K, Sugimoto T, Yamazaki Y, Takeda A, Uchinuma E. Osteogenic potential, multipotency, and cytogenetic safety of human bone tissue-derived mesenchymal stromal cells (hBT-MSCs) after long-term cryopreservation. Kitasato Med J. 2014;44:95-103.

38. Moll G, Alm JJ, Davies LC, Von Bahr L, Heldring N, Stenbeck-Funke L, et al. Do cryopreserved mesenchymal stromal cells display impaired immunomodulatory and therapeutic properties? Stem Cells. 2014;32(9):2430-42.

39. Heino TJ, Alm JJ, Moritz N, Aro HT. Comparison of the osteogenic capacity of minipig and human bone marrow-derived mesenchymal stem cells. J Orthop Res. 2012;30(7):1019-25.

40. Luetzkendorf J, Nerger K, Hering J, Moegel A, Hoffmann K, Hoefers C, et al. Cryopreservation does not alter main characteristics of Good Manufacturing Process-grade human multipotent mesenchymal stromal cells including immunomodulating potential and lack of malignant transformation. Cytotherapy. 2015;17:186-98.

41. Hirose M, Kotobuki N, Machida H, Kitamura S, Ohgushi H, Tateishi T. Osteogenic potential of cryopreserved human bone marrow-derived mesenchymal cells after thawing in culture. Mater Sci Eng C. 2004;24(3):355-9.

42. Davies OG, Smith AJ, Cooper PR, Shelton RM, Scheven BA. The effects of cryopreservation on cells isolated from adipose, bone marrow and dental pulp tissues. Cryobiology. 2014;69(2):342-7.

43. Bissoyi A, Nayak B, Pramanik K, Sarangi SK. Targeting cryopreservationinduced cell death: a review. Biopreserv Biobank. 2014;12(1):23-34.

44. Carvalho KAT, Cury CC, Oliveira L, Cattaned RII, Malvezzi M, Francisco $J C$, et al. Evaluation of bone marrow mesenchymal stem cell standard cryopreservation procedure efficiency. Transplant Proc. 2008;40:839-41.

45. François M, Copland IB, Yuan S, Romieu-Mourez R, Waller EK, Galipeau J. Cryopreserved mesenchymal stromal cells display impaired immunosuppressive properties as a result of heat-shock response and impaired interferon- $\gamma$ licensing. Cytotherapy. 2012;14(2):147-52.

46. Zhu X, Yuan F, Li L, Zheng Y, Xiao Y, Yan F. Evaluation of canine bone marrow-derived mesenchymal stem cells after long-term cryopreservation. Zool Sci. 2013;30(12):1032-7.

47. Dominici M, Le Blanc K, Mueller I, Slaper-Cortenbach I, Marini F, Krause $\mathrm{D}$, et al. Minimal criteria for defining multipotent mesenchymal stromal cells. The International Society for Cellular Therapy position statement. Cytotherapy. 2006:8(4):315-7.

48. Tokumoto S, Sotome S, Torigoe I, Omura K, Shinomiya K. Effects of cryopreservation on bone marrow derived mesenchymal cells of a nonhuman primate. J Med Dent Sci. 2008;55:137-43.

49. Lauterboeck L, Saha D, Chatterjee A, Hofmann N, Glasmacher B. XenoFree Cryopreservation of bone marrow-derived multipotent stromal cells from Callithrix jacchus. Biopreserv Biobank. 2016;14:530-8.

50. Ginis I, Grinblat B, Shirvan MH. Evaluation of bone marrow-derived mesenchymal stem cells after cryopreservation and hypothermic storage in clinically safe medium. Tissue Eng Part C Methods. 2012;18(6):453-63.

51. Ock SA, Rho GJ. Effect of dimethyl sulfoxide (DMSO) on cryopreservation of porcine mesenchymal stem cells (pMSCS). Cell Transplant. 2011;20(8):1231-9.

52. Yuan Z, Lourenco SDS, Sage EK, Kolluri KK, Lowdell MW, Janes SM. Cryopreservation of human mesenchymal stromal cells expressing TRAIL for human anti-cancer therapy. Cytotherapy. 2016;18(7):860-9.

53. Squillaro T, Peluso G, Galderisi U. clinical trials with mesenchymal stem cells: an update. Cell Transplant. 2016;25(5):829-48.

54. Baust JM, Corwin W, Snyder KK, Van Buskirk R, Baust JG. Cryopreservation: evolution of molecular based strategies. Biobanking and cryopreservation of stem cells. Cham: Springer; 2016. p. 13-29.

55. Chatterjee A, Saha D, Niemann H, Gryshkov O, Glasmacher B, Hofmann N. Effects of cryopreservation on the epigenetic profile of cells. Cryobiology. 2017;74:1-7.

56. De Wolf C, Van De Bovenkamp M, Hoefnagel M. Regulatory perspective on in vitro potency assays for human mesenchymal stromal cells used in immunotherapy. Cytotherapy. 2017;19:784-97.

57. Robb KP, Fitzgerald JC, Barry F, Viswanathan S. Mesenchymal stromal cell therapy: progress in manufacturing and assessments of potency. Cytotherapy. 2019;21(3):289-306. 
58. Krampera M, Galipeau J, Shi Y, Tarte K, Sensebe L. Immunological characterization of multipotent mesenchymal stromal cells-The international society for cellular therapy (ISCT) working proposal. Cytotherapy. 2013;15(9):1054-61.

59. Galipeau J, Krampera M, Barrett J, Dazzi F, Deans RJ, DeBruijn J, et al. International Society for Cellular Therapy perspective on immune functional assays for mesenchymal stromal cells as potency release criterion for advanced phase clinical trials. Cytotherapy. 2016;18:151-9.

60. Samsonraj RM, Raghunath M, Nurcombe V, Hui JH, van Wijnen AJ, Cool SM. Concise review: multifaceted characterization of human mesenchymal stem cells for use in regenerative medicine. Stem Cells Transl Med. 2017;6(12):2173-85.

61. Martino M, Morabito F, Messina G, Irrera G, Pucci G, lacopino P. Fractionated infusions of cryopreserved stem cells may prevent DMSO- induced major cardiac complications in graft recipients. Haematologica. 1996:81(1):59-61.

62. Zenhäusern R, Tobler A, Leoncini L, Hess OM, Ferrari P. Fatal cardiac arrhythmia after infusion of dimethyl sulfoxide-cryopreserved hematopoietic stem cells in a patient with severe primary cardiac amyloidosis and end-stage renal failure. Ann Hematol. 2000;79:523-6.

63. Stamatovic D, Balint B, Tukic LJ, Elez M, Tarabar O, Ostojic G, et al. Severe neurotoxicity following peripheral blood stem cell transplantation. Bone Marrow Transplant. 2011;46:1110.

64. Windrum P, Morris TCM. Severe neurotoxicity because of dimethyl sulphoxide following peripheral blood stem cell transplantation. Bone Marrow Transplant. 2003;31:315.

65. Yong KW, Wan Safwani WKZ, Xu F, Wan Abas WAB, Choi JR, PingguanMurphy B. Cryopreservation of human mesenchymal stem cells for clinical applications: current methods and challenges. Biopreserv Biobank. 2015;13(4):231-9.

66. Al-Saqi SH, Saliem M, Quezada HC, Ekblad $\AA$, Jonasson AF, Hovatta O, et al. Defined serum- and xeno-free cryopreservation of mesenchymal stem cells. Cell Tissue Bank. 2015;16(2):181-93.

67. Pollock K, Sumstad D, Kadidlo D, McKenna DH, Hubel A. Clinical mesenchymal stromal cell products undergo functional changes in response to freezing. Cytotherapy. 2015;17(1):38-45.

68. Chinnadurai R, Copland IB, Garcia MA, Petersen CT, Lewis CN, Waller EK, et al. Cryopreserved MSCs are susceptible to T-cell mediated apoptosis which is partly rescued by IFNy licensing Raghavan. Stem Cells. 2016;34(9):2429-42

69. Holubova M, Lysak D, Vlas T, Vannucci L, Jindra P. Expanded cryopreserved mesenchymal stromal cells as an optimal source for graft-versus-host disease treatment. Biologicals. 2014;42(3):139-44.

70. Bieback K, Kuçi S, Schäfer R. Production and quality testing of multipotent mesenchymal stromal cell therapeutics for clinical use. Transfusion. 2019;59:2164-73.

71. Stacey GN, Connon CJ, Coopman K, Dickson AJ, Fuller B, Hunt CJ, et al. Preservation and stability of cell therapy products: recommendations from an expert workshop. Regen Med. 2017;12(5):553-64.

72. Lum JJ, Bauer DE, Kong M, Harris MH, Li C, Lindsten T, et al. Growth factor regulation of autophagy and cell survival in the absence of apoptosis. Cell. 2005;120(2):237-48.

73. Mason EF, Rathmell JC. Cell metabolism: An essential link between cell growth and apoptosis. Biochim et Biophys Acta Mol Cell Res. 2011;1813:645-54.

74. Baldari S, Di Rocco G, Piccoli M, Pozzobon M, Muraca M, Toietta G. Challenges and strategies for improving the regenerative effects of mesenchymal stromal cell-based therapies. Int J Mol Sci. 2017;18(10):2087.

75. Ward MR, Abadeh A, Connelly KA. Concise review: rational use of mesenchymal stem cells in the treatment of ischemic heart disease. Stem Cells Transl Med. 2018;7(7):543-50.

76. Baust JG, Snyder KK, Van Buskirk R, Baust JM. Integrating molecular control to improve cryopreservation outcome. Biopreserv Biobank. 2017;15(2):134-41.

77. Caplan Al. Mesenchymal stem cells: time to change the name! Stem Cells Transl Med. 2017;6:1445-51.

78. González DA, Pando RH, Lim MÁG, Fraustro SA, Garcia AT. Therapeutic strategies of secretome of mesenchymal stem cell. Stromal cells-structure, function, and therapeutic implications. London: IntechOpen; 2018.

79. Merino-González C, Zuñiga FA, Escudero C, Ormazabal V, Reyes C, NovaLamperti E, et al. Mesenchymal stem cell-derived extracellular vesicles promote angiogenesis: potencial clinical application. Front Physiol. 2016;7:24.

80. Gallina C, Turinetto V, Giachino C. A new paradigm in cardiac regeneration: the mesenchymal stem cell secretome. Stem Cells Int. 2015;2015:765846. https://doi.org/10.1155/2015/765846.

81. Duscher D, Barrera J, Wong VW, Maan ZN, Whittam AJ, Januszyk M, et al. Stem cells in wound healing: the future of regenerative medicine? A mini-review. Gerontology. 2016;62:216-25.

82. Vizoso FJ, Eiro N, Cid S, Schneider J, Perez-Fernandez R. Mesenchymal stem cell secretome: toward cell-free therapeutic strategies in regenerative medicine. Int J Mol Sci. 2017;18:1852.

83. Konala VBR, Mamidi MK, Bhonde R, Das AK, Pochampally R, Pal R. The current landscape of the mesenchymal stromal cell secretome: a new paradigm for cell-free regeneration. Cytotherapy. 2016;18:13-24.

84. Tolar J, Le Blanc K, Keating A, Blazar BR. Concise review: hitting the right spot with mesenchymal stromal cells. Stem Cells. 2010;28:1446-55.

85. Bruno S, Deregibus MC, Camussi G. The secretome of mesenchymal stromal cells: role of extracellular vesicles in immunomodulation. Immunol Lett. 2015;168:154-8.

86. Chinnadurai R, Rajan D, Qayed M, Arafat D, Garcia M, Liu Y, et al. Potency analysis of mesenchymal stromal cells using a combinatorial assay matrix approach. Cell Rep. 2018;22(9):2504-17.

87. Fung M, Yuan Y, Atkins H, Shi Q, Bubela T. Responsible translation of stem cell research: an assessment of clinical trial registration and publications. Stem Cell Rep. 2017;8:1190-201.

88. Daley GQ. The promise and perils of stem cell therapeutics. Cell Stem Cell. 2012;10(6):740-9.

89. Trounson A, McDonald C. Stem cell therapies in clinical trials: progress and challenges. Cell Stem Cell. 2015;17(1):11-22.

90. Marks PW, Witten CM, Califf RM. Clarifying stem-cell therapy's benefits and risks. N Engl J Med. 2017;376(11):1007-9.

91. Bruder SP, Jaiswal N, Haynesworth SE. Growth kinetics, self-renewal, and the osteogenic potential of purified human mesenchymal stem cells during extensive subcultivation and following cryopreservation. J Cell Biochem. 1997;64:278-94.

92. Kotobuki N, Hirose M, Machida H, Katou Y, Muraki K, Takakura Y, et al. Viability and osteogenic potential of cryopreserved human bone marrow-derived mesenchymal cells. Tissue Eng. 2005;11:663-73.

93. Xiang Y, Zheng Q, Jia B, Huang G, Xie C, Pan J, et al. Ex vivo expansion, adipogenesis and neurogenesis of cryopreserved human bone marrow mesenchymal stem cells. Cell Biol Int. 2007;31:444-50.

94. Zhao ZG, Li WM, Chen ZC, You Y, Zou P. hematopoeisis capacity immunomodulatory effect andex vivo expasion poetntial of mesenhcymal stem cells are not impaired by cryopreservation. Cancer Invest. 2008;26(4):391-400.

95. Doan CC, Truong NH, Vu NB, Nguyen TT, Nguyen HM, Nguyen KG, et al. Isolation, culture and cryopreservation of human bone marrow-derived mesenchymal stem cells. Int J Plant Anim Environ Sci. 2012;2(2):83-90.

96. Li H, Yan F, Lei L, Li Y, Xiao Y. Application of autologous cryopreserved bone marrow mesenchymal stem cells for periodontal regeneration in dogs. Cells Tissues Organs. 2009;190(2):94-101.

97. Nitsch S, Chatterjee A, Hofmann N, Glasmacher B. Impact of cryopreservation on histone modifications of mesenchymal stem cells. In: Biomedizinische Technik. 2014;59:S294-7.

98. Romanek J, Opiela J, Lipiński D, Smorąg Z. Effect of high hydrostatic pressure applied before cryopreservation on the survival rate and quality of porcine mesenchymal stem cells after thawing. Anim Biotechnol. 2018;29(4):283-92.

\section{Publisher's Note}

Springer Nature remains neutral with regard to jurisdictional claims in published maps and institutional affiliations. 